\title{
ПЕДАГОГІКА І ПСИХОЛОГІЯ \\ БЕЗПЕКИ ЖИТТЄДІЯЛЬНОСТІ
}

\author{
За результатами VI Міжнародної науково-практичної конференції \\ «/нфрормаційно-комунікаційні технології в сучасній освіті: досвід, \\ проблеми, перспективи»
}

https://doi.org/10.37472/2707-305X-2021-3-2-3-6

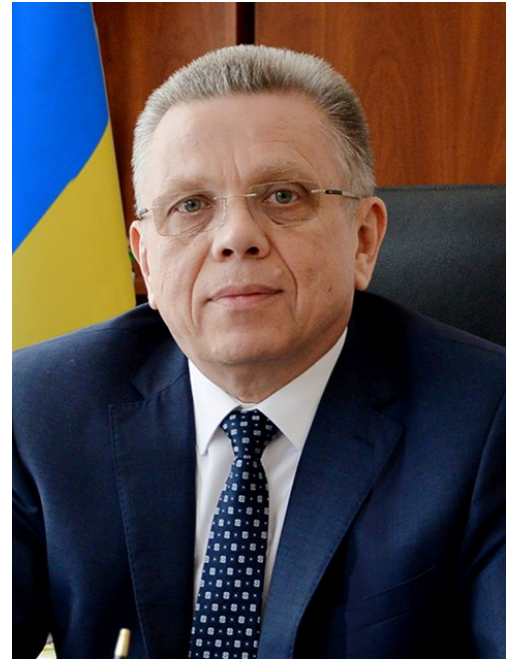

КОВАЛЬ

\section{Мирослав Стефанович}

доктор педагогічних наук, профресор, ректор

Львівського державного університету безпеки життєдіяльності, м. Львів, Україна

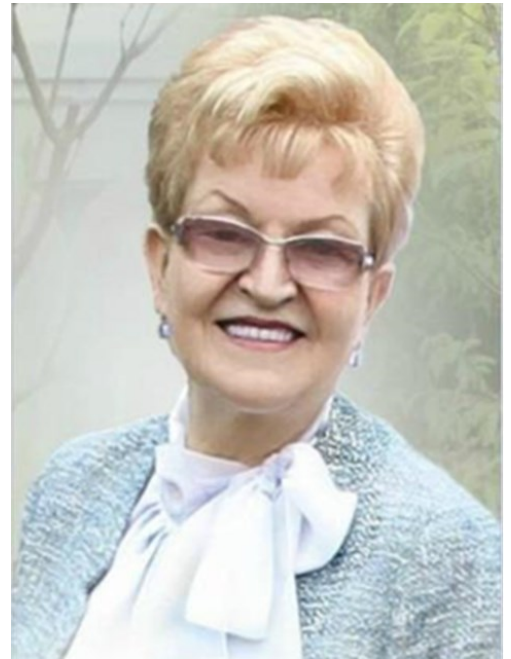

\section{НИЧКАЛО}

\section{Нелля Григорівна}

доктор педагогічних наук, профресор, дійсний член (академік) НАПН України, академік-секретар Відділення профресійної освіти і освіти дорослих Начіональної академі педагогічних наук України, м. Київ, Україна

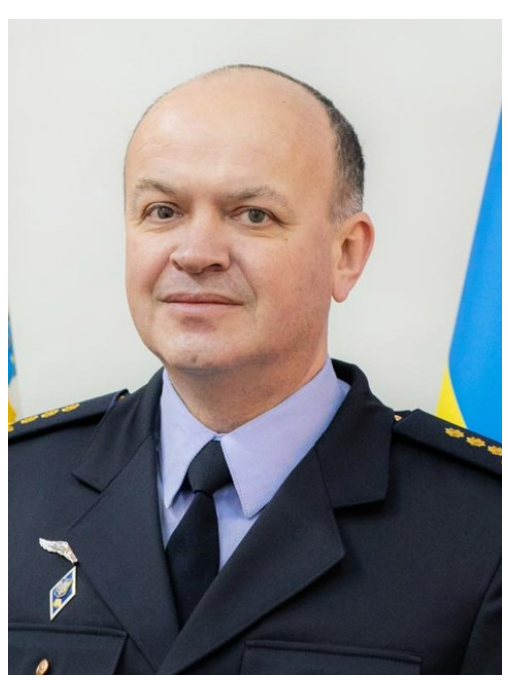

КУЗИК

\section{Андрій Данилович}

доктор сільськогосподарських наук, професор, проректор 3 науково-дослідної роботи Львівського державного університету безпеки життєдіяльності, м. Львів, Україна
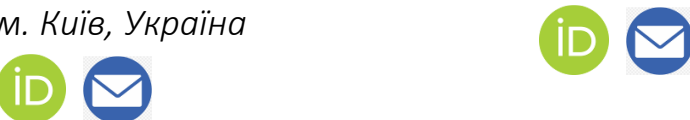

Анотація. У статmі розглянуті та охарактеризовані різні аспекти підготовки і проведення та узагальнені результати VI Міннародної науково-практичної конференції «Інформаційно-комунікаційні технології в сучасній освіті: досвід, проблеми, перспективи». Конференція відбулася 4-5 листопада 2021 року у Львівському державному університеті безпеки життєдіяльності відповідно до плану роботи Державної служби України з надзвичайних ситуацій та Начіональної академії педагогічних наук України. ї̈ проведення започатковано у 2006 році Міністерством надзвичайних ситуачій України та НАПН України.

Організатори цьогорічної конференції: Начіональна академія педагогічних наук України, Відділення профресійної освіти і освіти дорослих НАПН України, Інститут педагогічної освіти і освіти дорослих імені Івана Зязюна НАПН України, Інститут професійно-технічної освіти НАПН України, Інститут інформаційних технологій та засобів навчання НАПН України, Львівський державний університет безпеки життєдіяльності як структурний підрозділ Державної служби України з надзвичайних ситуацій та Департамент освіти $і$ науки Львівської обласної державної адміністрації.

На пленарних засіданнях виступили з науковими доповідями вітчизняні та зарубіжні вчені - знані фахівиі у сфері професійної педагогіки та педагогіки і психології безпеки життєдіяльності. В їхніх доповідях викладені 
теоретичні засади, досвід використання інформаційно-комунікаційних технологій (ІКТ) в освітньому процесі сучасних закладів освіти та обгрунтовані перспективи цифровізації підготовки фахівців нової генерації.

Цікаві дискусії відбулися на засіданнях чотирьох секцій:

1. Цифрова трансформація освіти і науки: стан і перспективи. Цифровізація підготовки здобувачів освіти у закладах освіти різних рівнів. Проблеми сучасної кібербезпеки, психопедагогіки безпеки, культура безпеки професійної діяльності фрахівиів.

2. Теорія і практика проєктування інформаційно-освітнього середовища у професійній підготовщі фахівців. Науково-методичні засади впровадження інформаційно-комунікаційних технологій в освітній процес закладів формальної і неформальної освіти.

3. Актуальні психолого-педагогічні проблеми професійної підготовки фахівців в умовах змішаного навчання.

4. Підготовка педагогів закладів формальної і неформальної освіти до створення та використання електронних освітніх ресурсів. Інформаційні технології у наукових дослідженнях. Менеджмент інноваційних освітніх проєктів, програм, підготовка грантів. Роботою секцій керували знані вчені та педагоги закладів вищої освіти.

Під час конференції відбувся обмін інновачійним досвідом використання ІКТ у закладах освіти. Учасники конференції взяли участь у семінарах, воркшопах, майстер-класах і тренінгах, що проводили науковопедагогічні працівники Львівського державного університету безпеки життєдіяльності, а також інших закладів освіти, установ і компаній, що здійснюють виробничу та освітню діяльність у сфері інформаційних технологій.

На підсумковому засіданні обговорено результати роботи секцій, обгрунтовано висновки та пропозиції до рекомендацій конференції. Найважливіші з них викладено у цій статmі. Всього у пленарних, секційних засіданнях та інших заходах взяли участь понад 100 осіб з 7 країн - Болгарії, Великої Британії, Канади, Молдови, Німеччини, Польщі та України, 60 з них виступили з науковими доповідями і повідомленнями.

у статті також висвітлено організаційно-технічні аспекти проведення конференції, зокрема використання онлайн-платформи Zоот та системи менеджменту конференцій Indico.

За результатами обговорення актуальних проблем використання IКТ у сучасній освіті запропоновано інноваційні підходи та методики організації освітнього процесу в закладах вищої освіти в умовах цифровізації. Ідеї інноваційного досвіду застосування ІКТ рекомендовано впроваджувати в освітній процес закладів освіти різних типів і форм власності, особливо дистанційного та змішаного навчання в умовах пандемії COVID-19.

Ключові слова: педагогіка; психологія; безпека життєдіяльності; професійна підготовка; інформаційнокомунікаційні технології; цифровізація.

Наукова конференція є одним із найважливіших наукових заходів, що дає змогу презентувати результати своїх досліджень та ознайомитись 3 досягненнями інших наукових шкіл, творчих колективів, взяти участь у дискусіях, обмінятися досвідом, налагодити ділові зв'язки з представниками інших закладів освіти, наукових установ і організацій. Особливо актуальним є обмін досвідом для спільноти педагогів, які постійно здійснюють творчий пошук форм і методів навчання, вдосконалюють свій рівень викладання, застосовують передові технології навчання в сучасних умовах. Найбільш актуальними нині в освітній діяльності $€$ IKT, що не лише підвищують ефективність процесу навчання, викладання та перевірки рівня знань, дозволяють продемонструвати навчальний матеріал засобами мультимедіа, а й забезпечують комунікацію учасників в умовах дистанційної освіти, з необхідністю якої людство зіткнулося в зв'язку з загрозами, спричиненими пандемією COVID-19. Тому і виникає необхідність проведення різноманітних наукових заходів, присвячених інформаційним технологіям та їх застосуванню в освіті. Одним із них є Міжнародна науково-практична конференція «Інформаційно- комунікаційні технології в сучасній освіті: досвід, проблеми, перспективи», що вже стала традиційною і вшосте проводиться у Львівському державному університеті безпеки життєдіяльності.

Метою cmammi є аналіз досвіду використання інформаційних технологій і результатів проведення VI Міжнародної науково-практичної конферениіі «/нформачійно-комунікаційні технології в сучасній освіті: досвід, проблеми, перспективи», що проводилася 4-5 листопада 2021 року як платформа для обговорення вітчизняними та та зарубіжними науковцями і практичними працівниками результатів досліджень, для обміну інноваційним досвідом та окреслення перспектив розвитку співпраці з цього напряму вітчизняних і зарубіжних закладів освіти.

Ідея проведення конференції з цієї проблеми виникла ще в 2006 році як результат співпраці Львівського державного університету безпеки життєдіяльності (ЛДУ БЖД) та Національної академії педагогічних наук України (НАПН України). Ії̈ ініціаторами були доктор педагогічних наук, професор, член-кореспондент НАПН України, генерал-лейтенант служби цивільного захисту Михайло Козяр, доктор педагогічних наук, профе- 
сор, полковник служби цивільного захисту Мирослав Коваль і доктор педагогічних наук, профеcop, дійсний член (академік) НАПН України Нелля Ничкало. Відтоді цей захід став традиційним, надаючи науковцям і практикам можливість збиратися, обмінюватися досвідом та обговорювати актуальні проблеми педагогіки і психології безпеки життєдіяльності, сучасних інформаційних технологій.

Розкриємо основні аспекти проведення цієї конференції у 2021 році та висновки і рекомендації за ії результатами.

Організатори конференції. Організаторами науково-практичної конференції у 2021 році вже традиційно виступили НАПН України та ї̈ наукові установи, зокрема Інститут педагогічної освіти і освіти дорослих імені Івана Зязюна, Інститут професійно-технічної освіти, Інститут інформаційних технологій та засобів навчання; Державна служба України з надзвичайних ситуацій та їі структурний підрозділ - ЛДУ БЖД, а також Департамент освіти і науки Львівської обласної державної адміністрації. Організаційний комітет очолили ректор ЛДУ БЖД, доктор педагогічних наук, професор Мирослав Коваль та доктор педагогічних наук, професор, дійсний член (академік) НАПН України, академік-секретар Відділення професійної освіти і освіти дорослих НАПН України Нелля Ничкало. До складу організаційного комітету увійшли науковці - знані дослідники проблем інформаційно-комунікаційних технологій в освітній галузі. Організаційний комітет визначив основні наукові напрями роботи конференції, сформував інформаційний лист з умовами участі та надіслав запрошення у вітчизняні та зарубіжні освітні заклади й наукові установи. Інформаційний лист оприлюднено на сайті університету та створено окремий вебсайт конференції (рис. 1).

Після завершення реєстрації учасників організаційний комітет сформував програму конференції (рис. 2).

Робота конференції. Для участі у конференції зареєструвалися та надіслали матеріали 116 наукових, науково-педагогічних і практичних працівників, аспірантів, докторантів, у тому числі 33 доктори і 26 кандидатів наук. У роботі пленарних, секційних засідань, семінарів, воркшопів, майстер-класів та тренінгів взяли участь дійсні члени (академіки) і члени-кореспонденти НАПН України, представники освітніх закладів, наукових установ, громадських організацій Болгарії,

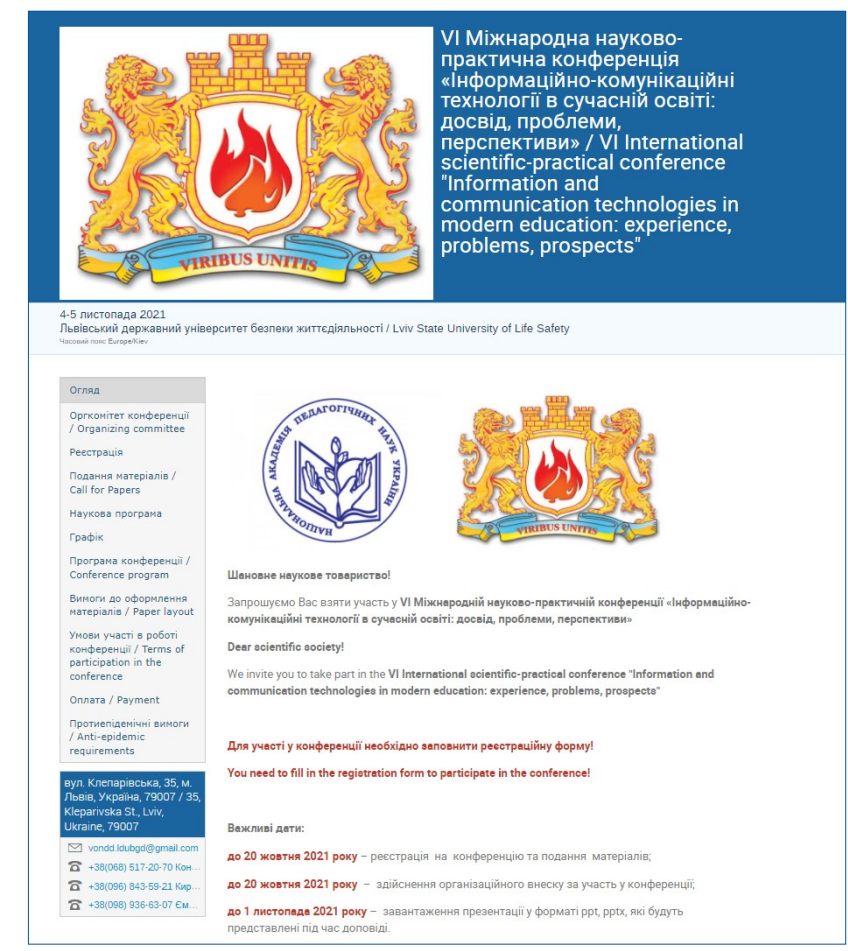

Рис. 1. Головна сторінка вебсайту VI Міжнародної науково-практичної конференції «Інформаційнокомунікаційні технології в сучасній освіті: досвід, проблеми, перспективи» в системі Indico

Великої Британії, Канади, Молдови, Німеччини, Польщі та України.

Пленарне засідання. Пленарне засідання проводилося у залі засідань спеціалізованих вчених рад лдУ БЖД (фото 1). Перед початком пленарного засідання учасникам конференції було продемонстровано документальний фільм, присвячений практичній підготовці курсантів у Львівському державному університеті безпеки життєдіяльності (додаток).

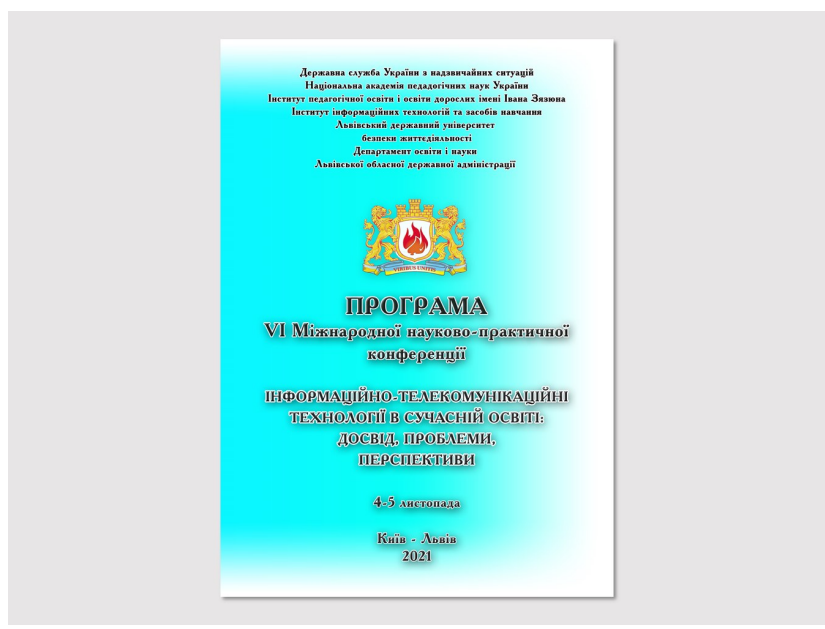

Рис. 2. Титульна сторінка програми VI Міжнародної науково-практичної конференції «|нформаційнокомунікаційні технології в сучасній освіті: досвід, проблеми, перспективи» 


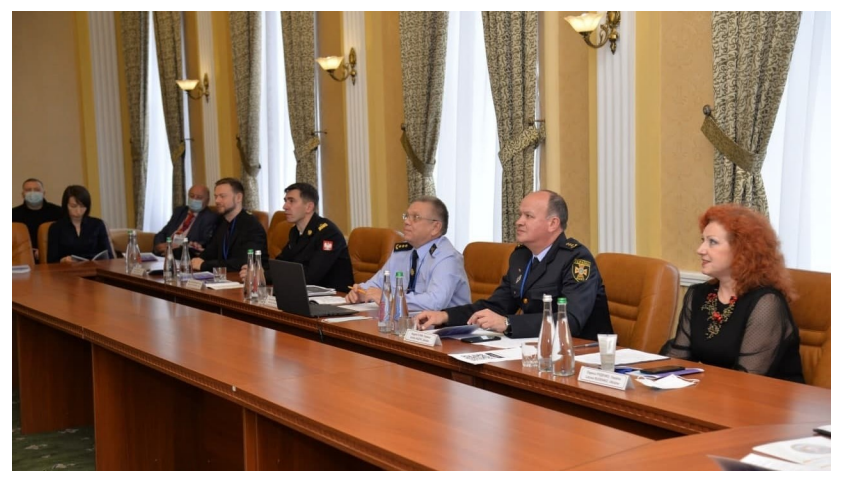

Фото 1. Відкриття конференції

Конференція розпочалася з вітального слова ректора ЛДУ БЖД, доктора педагогічних наук, професора, полковника служби цивільного захисту Мирослава Коваля (фото 2), який привітав ії учасників від імені колективу університету, висловив повагу і вдячність НАПН України, закладам освіти, науковим установам України і зарубіжних держав, представники яких беруть участь у роботі заходу. Ректор наголосив на важливості співпраці у різних сферах діяльності, а також привернув увагу до того, що розвиток інновацій у всіх видах діяльності людини об'єктивно зумовлює потребу модернізації системи освіти, необхідність широкого впровадження ІКТ.

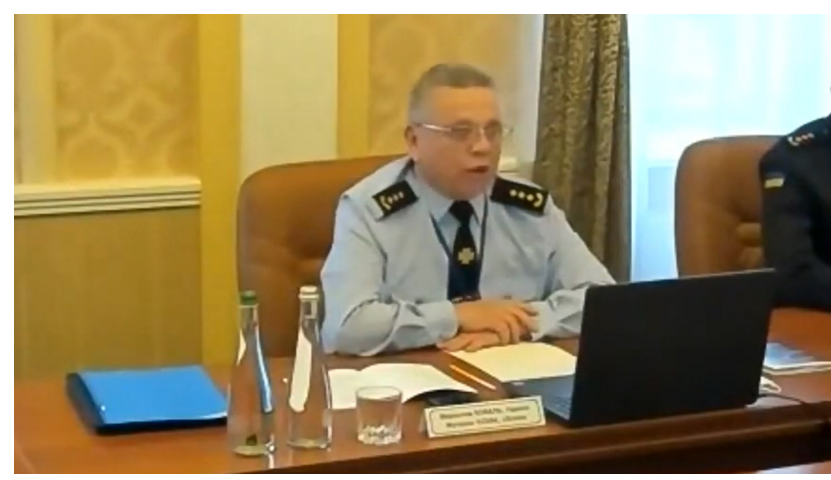

Фото 2. Вітальне слово Мирослава Коваля, ректора

ЛДУ БЖД, доктора педагогічних наук, професора, полковника служби цивільного захисту

Від імені НАПН України учасників конференції привітав доктор філософських наук, професор, академік НАН України, дійсний член (академік) НАПН України, президент НАПН України, президент товариства «Знання» України та Почесний доктор (Doctor Honoris Causa) ЛДУ БЖД Василь Кремень (фото 3). Він наголосив на тому, що актуальність конференції зумовлена динамічним розвитком сучасної цивілізації та інформаційнокомунікаційних технологій, які стали об'єктивною реальністю і займають щораз більше місця в житті людини і суспільства, зокрема в умовах пандемії COVID-19. Василь Кремень зазначив, що

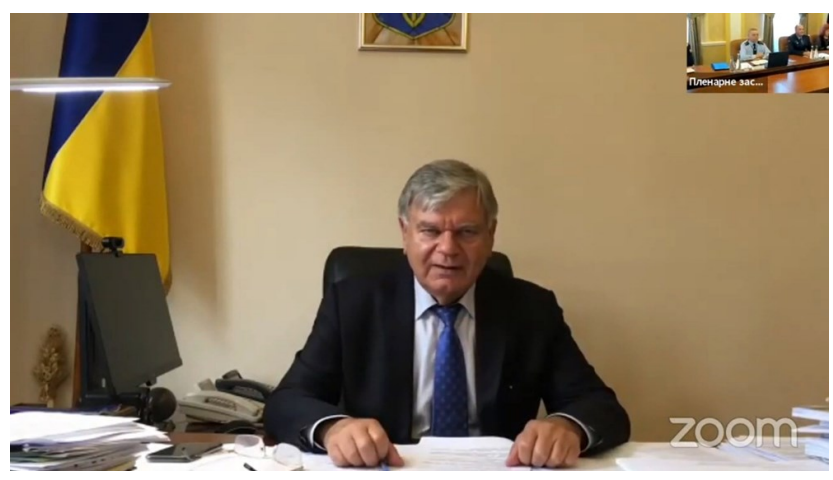

Фото 3. Учасників конференції вітає Василь Кремень, доктор філософських наук, професор, академік Національної академії наук України, дійсний член (академік) НАПН України, президент НАПН України, президент товариства «Знання» України, Почесний доктор (Doctor Honoris Causa) ЛДУ БЖД

після завершення пандемії освіта вже не буде такою, якою вона була до ії початку, акумулюючи та інтегруючи кращі сторони дистанційної освіти. Суспільство має усвідомити важливість цих технологій у житті та освіті, як шлях до комп'ютерної грамотності та можливості спілкуватися з усім світом.

Модераторами пленарного засідання були проректор з науково-дослідної роботи ЛДУ БЖД, доктор сільськогосподарських наук, професор Андрій Кузик та професор кафедри практичної психології та педагогіки університету, доктор педагогічних наук, професор Лариса Руденко. 3 науковими доповідями на пленарних засіданнях виступили вчені України, Великої Британії, Польщі та Канади. Особливу увагу було приділено висвітленню теоретичних засад, актуальних проблем і перспективних напрямів педагогіки і психології безпеки життєдіяльності, творчому використанню ІКТ в освітній діяльності, що викликало зацікавлення у присутніх.

Розкриємо зміст окремих доповідей, виголошених на пленарних засіданнях. Етапи формування інформаційно-освітнього середовища у Львівському державному університеті безпеки життєдіяльності та його основні компоненти розкрив доктор педагогічних наук, професор Мирослав Коваль (фото 4), зосередивши увагу на класифікації цих компонентів. Доповідач наголосив, що основними напрямами впровадження інформаційно-освітнього середовища в діяльність університету $є$ навчальна, наукова, виховна діяльність, управління освітнім процесом, управління ресурсами та практична професійно-екстремальна підготовка. Мирослав Коваль продемонстрував приклади навчально-наукових комплексів, лаборато- 

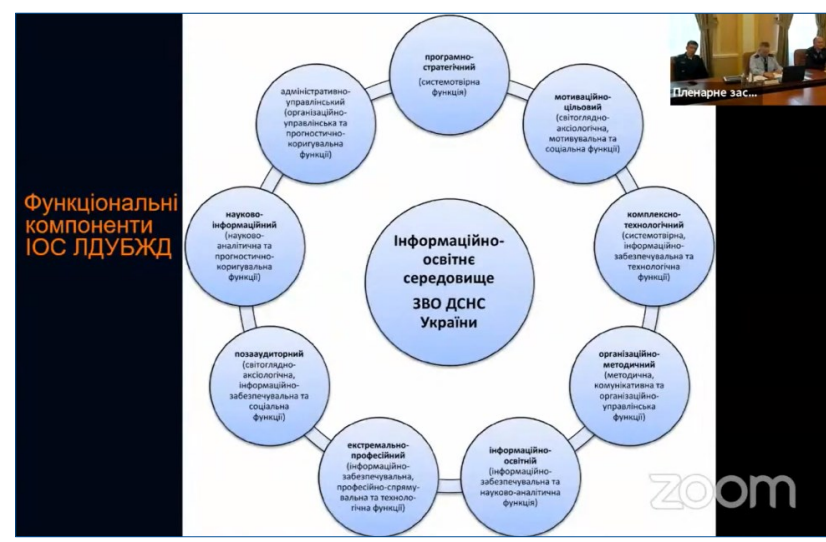

Фото 4. Ректор ЛДУ БЖД, доктор педагогічних наук, професор Мирослав Коваль виступає з доповіддю «Компоненти інформаційно-освітнього середовища

Львівського державного університету безпеки життєдіяльності»

рій та тренінгових центрів, в основу діяльності яких покладено інформаційні технології, а також поділився планами подальшої розбудови інформаційно-освітнього середовища в умовах цифровізації.

Методологічні проблеми формування і розвитку субдисциплін педагогічної науки проаналізовано у доповіді доктора педагогічних наук, професора, дійсного члена (академіка) НАПН України, академіка-секретаря Відділення професійної освіти і освіти дорослих НАПН України, Почесного доктора (Doctor Honoris Causa) ЛДУ БЖД Неллі Ничкало (фото 5). Вона розпочала з положення, обґрунтованого відомим польським вченим, Почесним доктором (Doctor Honoris Causa) НАПН України Богуславом Сліверським: «Педагогіка була, є і буде наукою наук на різних континентах, у різних культурах і навіть у віртуальному світі». Особливим явищем на міжнародному рівні стало заснування медіальної педагогіки. Це поняття обґрунтовано і введено у науковий обіг німець-

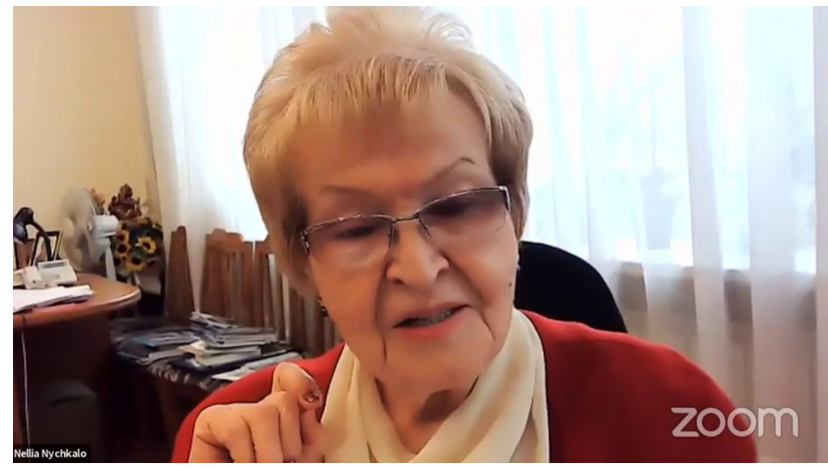

Фото 5. Виступає Нелля Ничкало, доктор педагогічних наук, професор, дійсний член (академік) НАПН України, академік-секретар Відділення професійної освіти і освіти дорослих НАПН України, Почесний доктор (Doctor Honoris Causa) ЛДУ БЖД ким вченим А. Аустерманном (A. Austermann). У Польщі цю категорію науково обґрунтував у 1983 р. Л. Бандура (L. Bandura). У Комітеті педагогічних наук Польської академії наук вже давно активно діє секція медіальної педагогіки. у 2007 р. видано академічний підручник «Медіальна педагогіка» у 2-х томах за науковою редакцією Б. Сємєнєцького (В. Siemieniecki). Характеризуючи медіальну педагогіку у контексті міждисциплінарності, доповідачка привернула увагу до актуальності і необхідності дослідження цифрової гуманістичної педагогіки відкритої освіти (В. Биков, М. Лещенко), «персоналістичної концепції людини як антроподопоміжної бази медіальної педагогіки» (Ян Павло ІІ), а також візуальної грамотності в освітньому процесі та її експлікації в культурі мислення (В. Кремень, В. Ільїн).

Досвід формування і розвитку інформаційнокомунікаційної компетентності майбутніх фахівців за останні 20 років в Україні проаналізувала Лариса Лук'янова - доктор педагогічних наук, професор, член-кореспондент НАПН України, директор Інституту педагогічної освіти і освіти дорослих імені Івана Зязюна НАПН України (фото 6). Вона наголосила на важливості процесу інформатизації, що визначається як готовність населення країни до використання переваг та можливостей сучасних IKT. Таку готовність може сформувати тільки відповідно підготовлений вчитель.

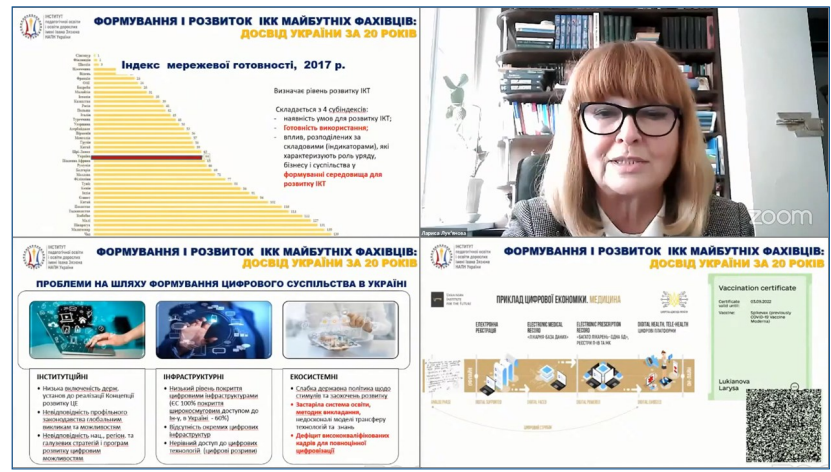

Фото 6. Доктор педагогічних наук, професор, членкореспондент НАПН України, директор Інституту педагогічної освіти і освіти дорослих імені Івана Зязюна НАПН України Лариса Лук'янова виступає на пленарному засіданні

У доповіді узагальнено результати аналізу дисертацій, присвячених проблемам формування і розвитку інформаційно-комунікаційної компетентності майбутніх учителів у процесі професійної підготовки в педагогічних університетах України. Це одна із ключових компетентностей учителя, котру дисертанти розглядають як складову про- 
фесійної компетентності або трактують ї̈ як якість фахівця, структурний компонент або складову іншої якості, компетентності чи підготовки. Виявлення особливостей формування досліджуваної якості здійснювалося у процесі вивчення, систематизації та узагальнення дисертаційних праць, захищених у спеціалізованих радах України впродовж 2010-2020 років.

У доповіді Романа Гуревича, доктора педагогічних наук, професора, дійсного члена (академіка) НАПН України, директора Навчально-наукового інституту педагогіки, психології, підготовки фахівців вищої кваліфікації Вінницького державного педагогічного університету імені Михайла Коцюбинського, Почесного доктора (Doctor Honoris Causa) ЛДУ БЖД (фото 7) «Цифровізація сучасної освіти: напрями, можливості, проблеми, ризики» розглянуто проблеми цифровізації освіти на етапі переходу від традиційних форм до переважно дистанційних, коли зростає активність використання нових технологій (віртуальної та доповненої реальності), моделювання за допомогою комп'ютерів, різних соціальних мереж і хмарних додатків. Здійснено аналіз концептуальних вимог до учасників освітнього процесу під час застосування сучасних прогресивних освітніх цифрових технологій. Доведено, що феномен цифрової освіти, як однієї з ключових реалій життєдіяльності сучасної людини, призводить поки що переважно до поглиблення суперечностей в освіті. При переході до цифровізації освіти критично важливо зберегти сучасне «аналогове» багатство, що $\epsilon$ фундаментом класичної системи освіти.

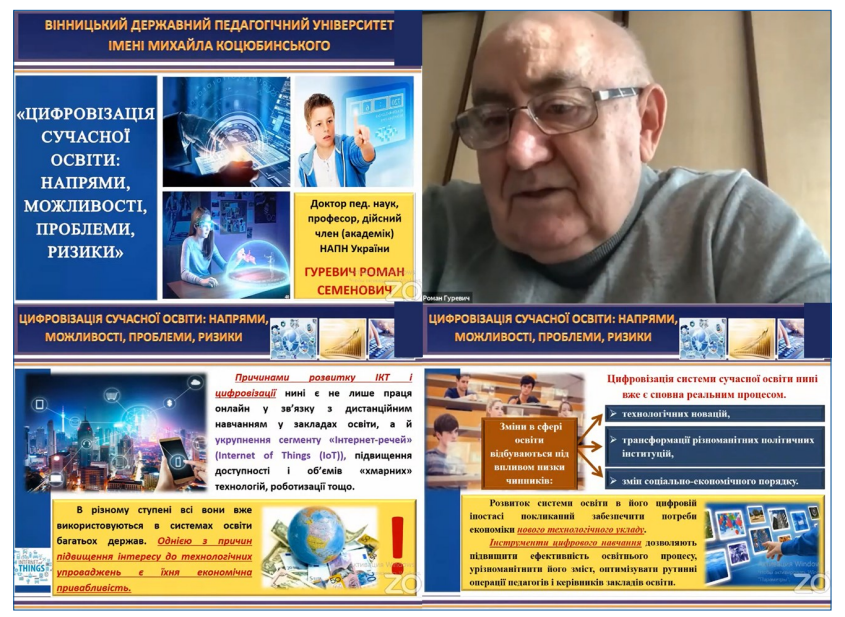

Фото 7. Доповідає Роман Гуревич, доктор педагогічних наук, професор, дійсний член (академік) НАПН України, директор Навчально-наукового інституту педагогіки, психології, підготовки фахівців вищої кваліфікації Вінницького державного педагогічного університету імені Михайла Коцюбинського
Висвітленню технологій застосування безпілотних літальних апаратів для навчання рятувальників та їх використання в майбутній професійній діяльності присвячувалась доповідь доктора інженерії, ректора-коменданта, професора Головної школи пожежної служби у Варшаві Маріуша Фельтиновського (фото 8). Доповідач проаналізував параметри літальних апаратів та відеокамер, висвітлив позитивні та негативні аспекти застосування тепловізійних камер, а також навів приклади застосування дронів під час гасіння лісових пожеж, проведення рятувальних робіт в аварійних будівлях та обстеження територій, що постраждали від природних та техногенних катастроф.

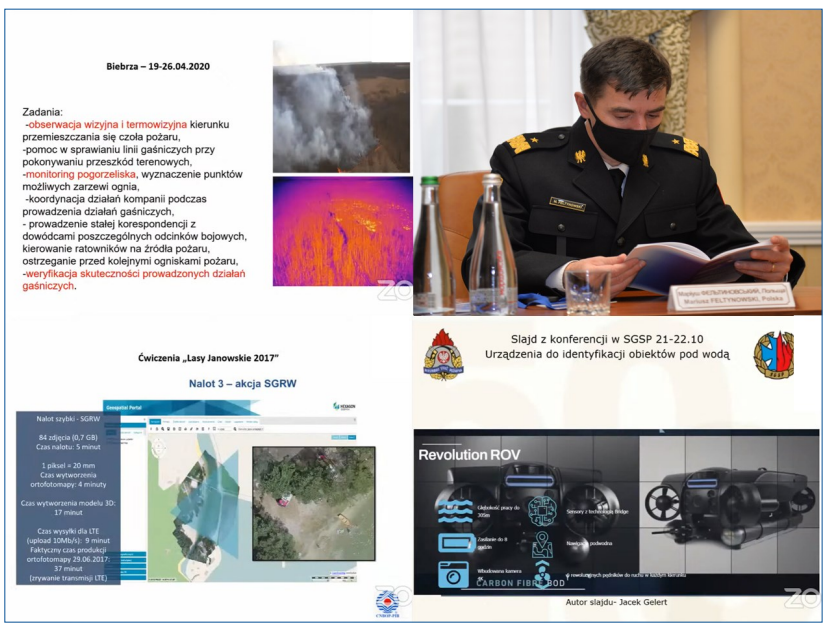

Фото 8. Про результати досліджень ефективності

застосування безпілотних літальних апаратів в процесі підготовки рятувальників інформує Маріуш Фельтиновський, доктор інженерії, ректор-

комендант, професор Головної школи пожежної служби у Варшаві, Республіка Польща

До проблем інформаційної безпеки в соціокультурному просторі України привернув увагу Георгій Філіпчук - доктор педагогічних наук, професор, дійсний член (академік) НАПН України, Перший заступник Голови Всеукраїнського товариства «Просвіта» імені Тараса Шевченка (фото 9). Доповідач наголосив на тому, що високий інтелектуальний доробок, сформований українською нацією, українським народом робить нашу націю значимою в світі, зокрема і у галузі інформаційних технологій. Набувають особливого значення питання інформаційної безпеки як складової національної безпеки не лише у сфері IT, а й в інформаційному просторі, формуванні здоров'язбережувального середовища та підвищенні якості освіти, яка має бути креативною, критичною, комунікаційною і командною (колективною). Академік зазначив, що наша освіта з базових дисциплін відстає від сусідніх країн 


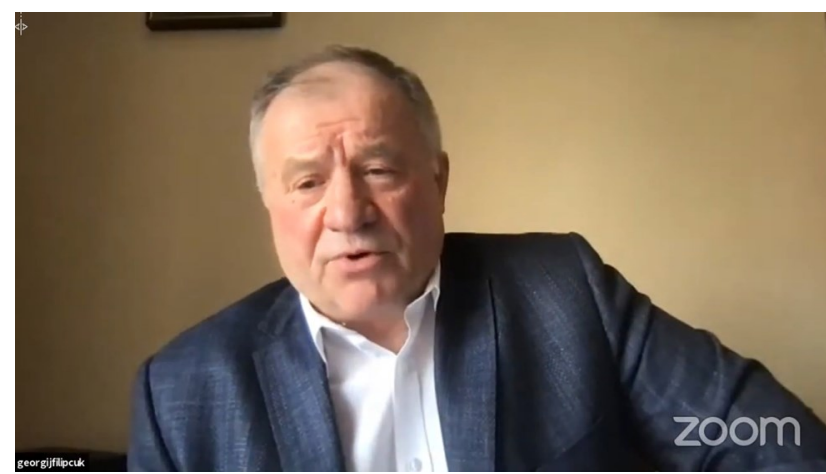

Фото 9. Доповідає Георгій Філіпчук, доктор педагогічних наук, професор, дійсний член (академік) НАПН України, перший заступник Голови Всеукраїнського товариства «Просвіта» імені Тараса Шевченка

Європи на один рік, а у сільській місцевості - на 2,5 роки. Тому для воюючої держави є актуальною відповідна науково-освітня політика з кібербезпеки, що має охоплювати 4 напрями: підвищення ефективності системи підготовки і перепідготовки, наукові дослідження, цифрову грамотність та максимальне залучення наукового потенціалу до створення інформаційних систем і вдосконалення змісту освіти, формування інформаційних навичок, обізнаності, компетентності в протидії кіберзагрозам.

Про досвід застосування інформаційних технологій в організації проєктів Erasmus+ між лДу БЖД та Кігстонським університетом йшлося у доповіді доктора Алана Флоуерса - координатора проєктів від Кінгстонського університету, з яким упродовж останніх п'яти років відбуваються обміни викладачами та студентами (фото 10). Доповідач також висвітлив питання використання інформаційних технологій в освітньому процесі університетів Великої Британії. На основі узагаль-

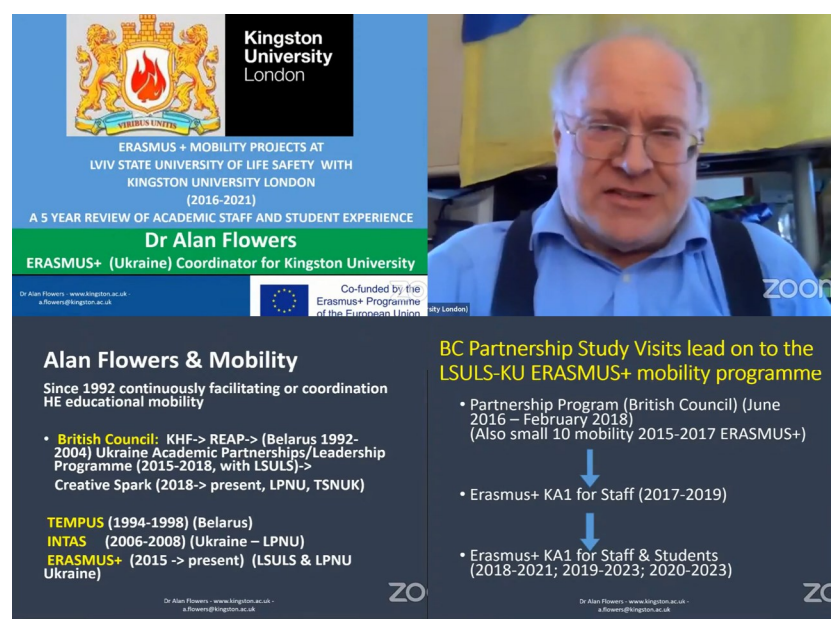

Фото 10. Доповідає доктор Алан Флоуерс, координатор проєктів Erasmus+ від Кінгстонського університету, Лондон нення результатів якісного аналізу він зазначив, що ЛДУ БЖД також має значні досягнення з цього напряму. Підвищенню ефективності співпраці також сприяють обміни викладачами та студентами в рамках європейських освітніх проєктів, під час яких учасники знайомляться з освітнім процесом, обмінюються інноваційним досвідом та налагоджують ділові контакти

Про унікальний проєкт «Antyfakenews», спрямований на розроблення програмного забезпечення для боротьби з фейковими новинами та розпізнавання недостовірної інформації в текстах і зображеннях, розповів Кароль Єндрасяк доктор інженерії, заступник директора Центру трансферу технологій Академії WSB, м. Домброва Гурніча, Республіка Польща (фото 11). Він обґрунтував необхідність боротьби з фейками в різних ситуаціях, зокрема в освітньому процесі, й зосередив увагу на трьох видах недостовірної інформації та навів приклади текстів і фотографій, інформацію з яких сприймають некоректно.

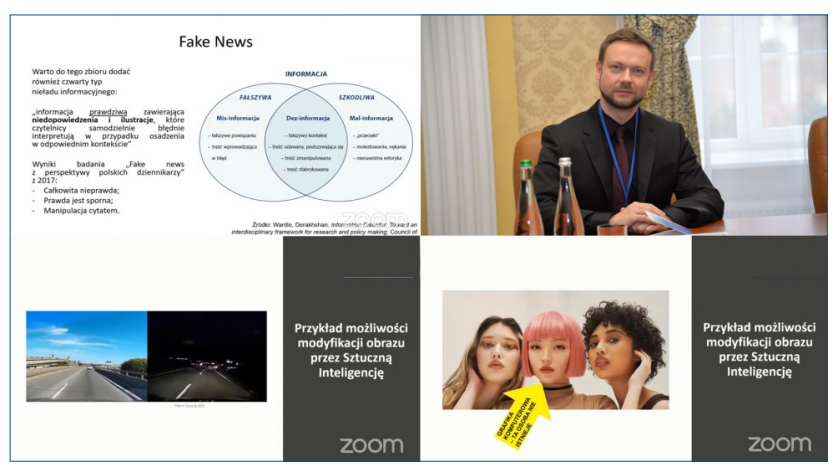

Фото 11. Доповідає доктор інженерії Кароль

Єндрасяк, заступник директора Центру трансферу технологій Академії WSB у м. Домброва Гурніча, Республіка Польща

У доповіді доктора Морін-Патриції Флагерті, доцента кафедри Студій миру і конфлікту Манітобського університету, м. Вінніпег, Канада висвітлювались проблеми усвідомленої освіти з позиції сильних сторін.

3 доповіддю «Створення SMART-комплексів навчальних дисциплін для підготовки кваліфікованих робітників» виступив доктор педагогічних наук, професор, науковий співробітник лабораторії електронних навчальних ресурсів Інституту професійно-технічної освіти НАПН України Микола Пригодій (фото 12). Дослідник проаналізував сучасний стан підготовки викладачів до використання IKT в освіті й обґрунтував необхідність запровадження інновацій, зокрема створення SMART-комплексів навчальних дисциплін. 3 урахуванням розробленої концептуальної моделі 


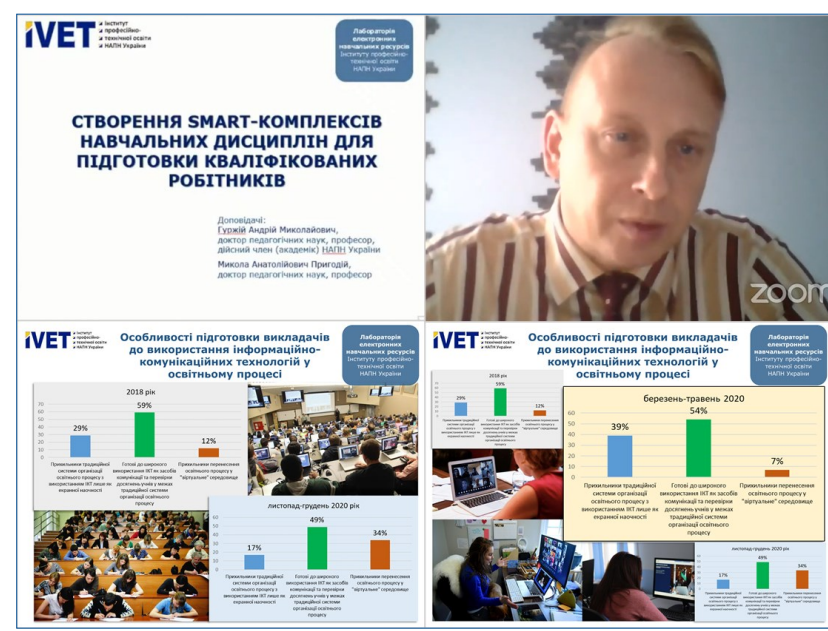

Фото 12. Доповідає Микола Пригодій, доктор педагогічних наук, професор, науковий співробітник

лабораторії електронних навчальних ресурсів Інституту професійно-технічної освіти НАПН України

запропоновано методику підготовки викладачів до розроблення SMART-комплексів навчальних дисциплін, що охоплює шість етапів: організаційноцільовий, змістовий, структурний, проєктувальний, узагальнювальний, процесуальний.

Доктор педагогічних наук, професор, професор кафедри практичної психології та педагогіки ЛДУ БЖД Андрій Литвин представив моделі інформатизації закладів вищої освіти. Він наголосив, що модернізація української вищої освіти потребує вироблення стратегії застосування у змісті та методах навчання найбільш продуктивних інновацій, що базуються на IKT. Запорукою успішного впровадження новітніх технологій $\epsilon$ розроблення дидактичної, технічної та методичної підтримки процесу використання IKT і відповідного науково-методичного забезпечення. На думку А. Литвина, це потребує обирання та затвердження певної моделі інформатизації 3ВО, а також підготовки і схвалення Програми інформатизації кожного закладу, що описує комплекс заходів усіх служб і підрозділів закладу, спрямованих на реалізацію IKT. Рамкова програма ЄC пропонує декілька далекосяжних моделей інформатизації освіти. Зокрема, стосовно вищої освіти до них відносять: модель університетського комплексу для закладів широкого профілю та еOxbridge (цифровий міст) для найстаріших топуніверситетів. Натомість вітчизняні науковці (В. Биков, Р. Гуревич, В. Кремень та ін.) найбільш перспективною моделлю інформатизації вищої школи вважають створення інформаційноосвітнього середовища ЗВО. Професійна підготовка, реалізована в цьому середовищі дає змогу підвищити інтенсивність і якість навчання та виховання майбутніх фахівців завдяки долученню до невичерпних ресурсів єдиного інформаційного освітнього простору й оптимізації організаційно-педагогічних умов використання IKT.

Секційні засідання. Після завершення пленарного засідання учасники конференції продовжили роботу в секціях. За допомогою засобів телекомунікацій учасникам конференції було продемонстровано в режимі прямої трансляції місця проведення секційних засідань, семінарів, воркшопів, майстер-класів та тренінгів (фото 13).

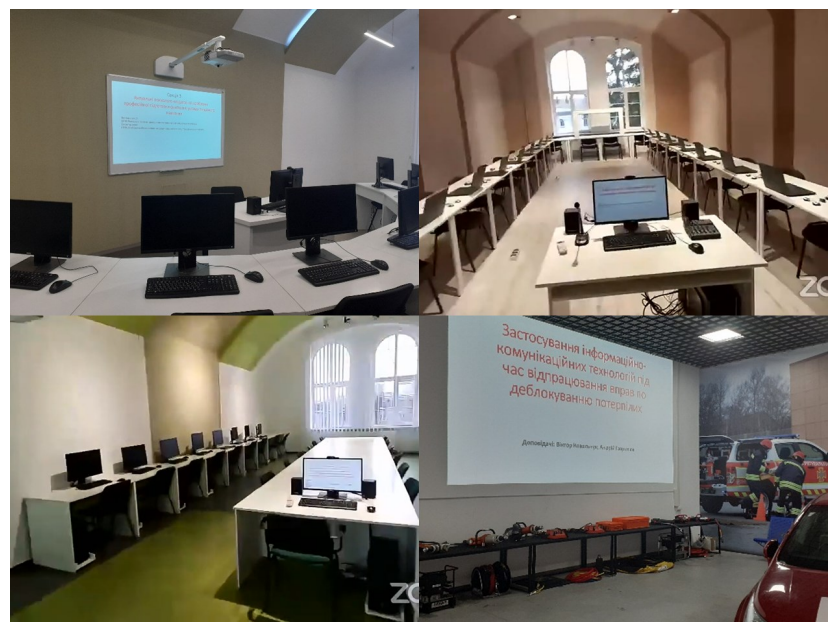

Фото 13. Демонстрація локацій проведення секційних засідань, семінарів, воркшопів, майстер-класів та тренінгів в режимі прямої трансляції

Керівництво секційними засіданнями здійснювали науково-педагогічні працівники ЛДУ БЖД знані науковці у галузі педагогіки, психології, безпеки життєдіяльності та інформаційних технологій.

Першою секцією «Цифрова трансформація освіти і науки: стан і перспективи. Цифровізація підготовки здобувачів освіти у навчальних закладах різних рівнів. Проблеми сучасної кібербезпеки, психопедагогіки безпеки, культура безпеки професійної діяльності фрахівців» керував доктор педагогічних наук, професор Григорій Васянович - почесний академік НАПН України, професор кафедри соціальної роботи, управління та суспільних наук. Секретар цієї секції - кандидат педагогічних наук, старший науковий співробітник Світлана Вдович - доцент кафедри практичної психології та педагогіки (фото 14). Цікавою була доповідь Олександри Скрабач з міста Слупск про навчання для безпеки на прикладі класів військової підготовки у Республіці Польща. Про використання ІКТ для формування професійної мотивації у майбутніх соціальних працівників розповів доктор педагогічних наук, професор Григорій Васянович. Кандидат педагогічних наук, доцент Любов Гутор 


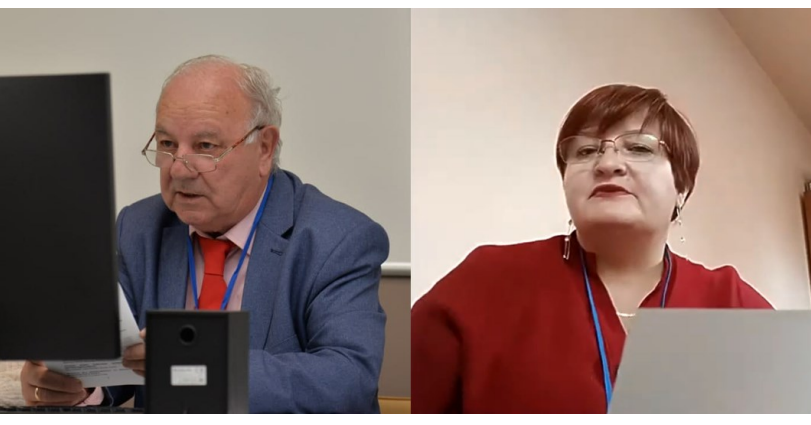

Фото 14. Засідання першої секції проводять професор кафедри соціальної роботи ЛДУ БЖД, доктор педагогічних наук, професор, почесний академік НАПН України Григорій Васянович і доцент кафедри практичної психології та педагогіки ЛДУ

БЖД, кандидат педагогічних наук, старший науковий співробітник Світлана Вдович

з Львівського медичного університету імені Данила Галицького в цікавій формі ознайомила наукову спільноту з майстерністю цифрової розповіді, зокрема представила досвід Японії. Психологічні особливості віртуального спілкування студентів в умовах диджиталізації, зокрема ефект інгібіції, були предметом дослідження доктора психологічних наук, професора Олени Кривопишиної професора кафедри практичної психології та педагогіки ЛДу БЖД. Досвід використання технологій дистанційного навчання в європейських університетах в умовах пандемії коронавірусу в своїй доповіді представив доктор філософії у галузі освіти Владислав Белан з Інституту професійно-технічної освіти НАПН України. Зокрема йшлося про такі країни, як Польща, Румунія, Словаччина, Угорщина, Чехія, Швейцарія та ін. Про проблеми вразливості комп'ютерної мережі як проблему закладів вищої освіти доповіла викладач кафедри управління інформаційною безпекою ЛДУ БЖД Валерія Балацька.

Друга секція «Теорія і практика проектування інформаційно-освітнього середовища у професійній підготовиі фрахівців. Науковометодичні засади впровадження інформаційнокомунікаційних технологій в освітній процес закладів формальної і неформальної освіти» проводилася під головуванням доктора педагогічних наук, професора Андрія Литвина - професора кафедри практичної психології та педагогіки (фото 15), секретар - кандидат педагогічних наук, викладач кафедри українознавства Тетяна Конівіцька. Тематика наукових повідомлень і дискусії стосувалася: стану і перспективи інформатизації освіти; теорії і практики проектування та реалізації інформаційно-освітнього середовища у професійній підготовці фахівців; науково-

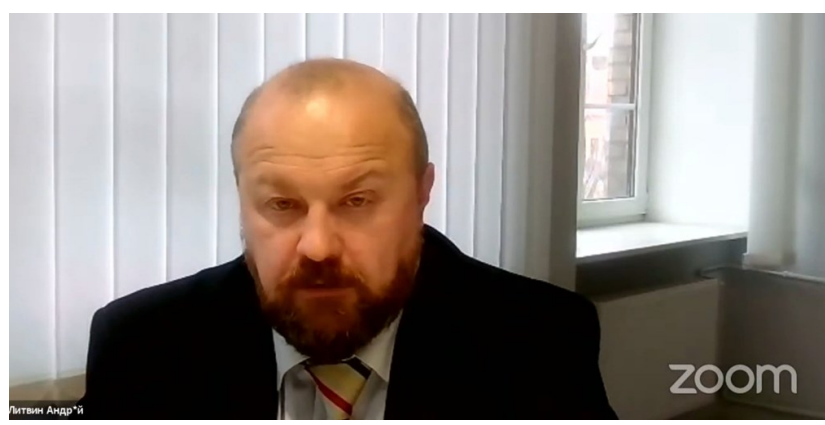

Фото 15. На засіданні другої секції головує професор кафедри практичної психології та педагогіки ЛДУ БЖД, доктор педагогічних наук, професор Андрій Литвин

методичних засад упровадження інформаційнокомунікаційних технологій в освітній процес; актуальних психолого-педагогічних проблем професійної підготовки фахівців в умовах дистанційного та змішаного навчання; підготовки педагогів закладів вищої освіти до створення та використання електронних освітніх ресурсів; проблем кібербезпеки в закладах освіти тощо. Викликали жваве зацікавлення можливості IKT для візуалізації математичної підготовки, виголошені в доповіді кандидата педагогічних наук, доцента Мирослави Кусій - доцента кафедри прикладної математики і механіки ЛДУ БЖД, проєктна діяльність на основі IКТ як інструмент формування компонентів професійної компетентності у доповіді кандидата технічних наук, доцента Олександра Придатка - начальника кафедри інформаційних технологій та телекомунікаційних систем лдУ БЖД, перспективні напрями інформатизації закладів вищої освіти у доповіді доктора педагогічних наук, професора Андрія Литвина і доктора педагогічних наук, професора Лариси Руденко, а також психологічні аспекти застосування IКТ в умовах змішаного навчання, проаналізовані кандидатом технічних наук, доцентом Ольгою Смотр доцентом кафедри інформаційних технологій та телекомунікаційних систем ЛДУ БЖД.

Третя секція «Актуальні психолого-педагогічні проблеми профресійної підготовки фрахівців в умовах змішаного навчання» (фото 16) проводилася під головуванням доктора психологічних наук доцента, начальника кафедри практичної психології та педагогіки Роксолани Сірко, секретар секції - Оксана Стельмах, кандидат психологічних наук, старший викладач кафедри практичної психології та педагогіки. 3 доповіддю виступив Ярослав Плюса з Варшави, наукові розробки якого стосувалися питань адаптації студентів спортивних університетів до навчання впродовж 


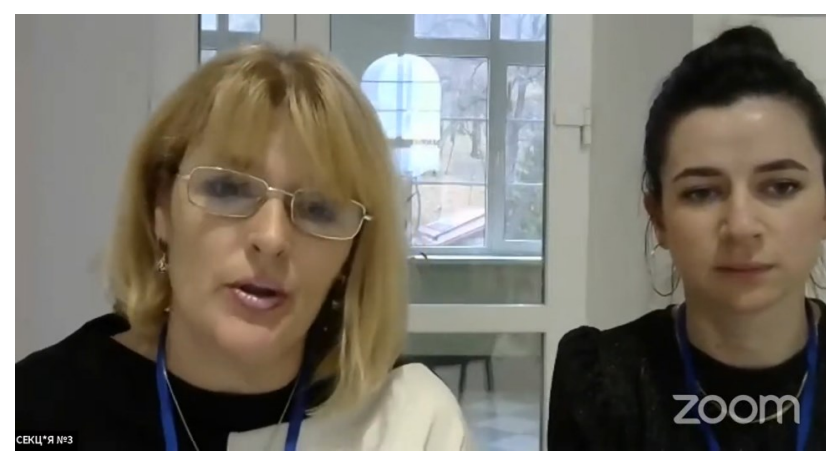

Фото 16. Засідання третьої секції проводять начальник кафедри практичної психології та педагогіки ЛДУ БЖД, доктор психологічних наук, доцент Роксолана Сірко та старший викладач цієї кафедри, кандидат психологічних наук Оксана Стельмах

карантинних обмежень. Інші доповіді стосувалися проблем професійної підготовки фахівців ризиконебезпечних професій (доктор педагогічних наук, доцент Роксолана Сірко), психологічного супроводу освітнього процесу закладів вищої освіти зі специфічними умовами навчання (кандидат педагогічних наук Ігор Коваль, заступник начальника відділу виховної, соціальногуманітарної роботи та психологічного забезпечення ЛДУ БЖД), проблемам змішаного навчання як новітньої педагогічної технології (викладач кафедри практичної психології та педагогіки ЛДу БЖД Роман Яремко, студентка 3 курсу лДу БЖД, спеціальність «Психологія» Світлана Агапова). Жваву дискусію викликала доповідь кандидата психологічних наук Оксани Стельмах, яка досліджувала питання впливу соціальних мереж на студентську молодь. Обговорювалися як позитивні, так і негативні наслідки впливу соціальних мереж, такі як кіберзалежність, зниження комунікативних навичок, викривлення Я-образу тощо.

Міждисциплінарною була тематика четвертої секції «Підготовка педагогів закладів формальної і неформальної освіти до створення та використання електронних освітніх ресурсів. Інформаційні технології у наукових дослідженнях. Менеджмент інноваційних освітніх проєктів, програм, підготовка грантів» під головуванням доктора технічних наук, професора Олега Зачка - професора кафедри права та менеджменту у сфері цивільного захисту, секретар цієї секції - кандидат технічних наук, докторант Дмитро Кобилкін (фото 17).

Доповідачами на цій секції були представники закладів освіти та наукових установ (фото 18). 3 доповідей варто відзначити працю старшого наукового співробітника Інституту педагогічної освіти і освіти дорослих імені Івана Зязюна НАПН

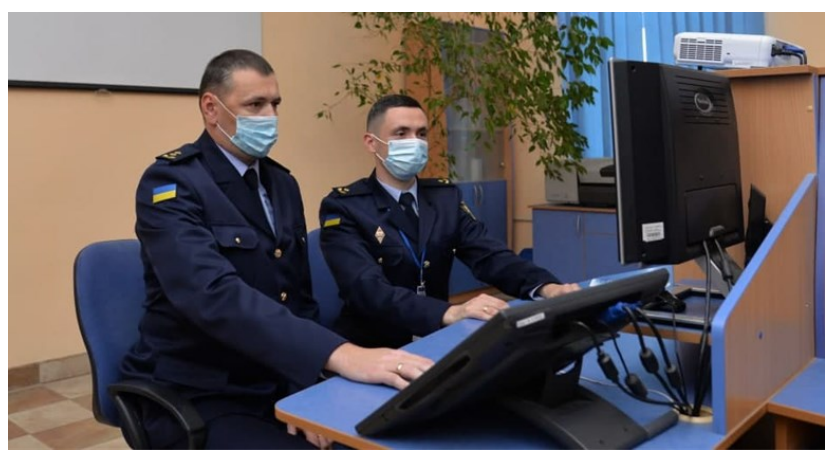

Фото 17. Засідання четвертої секції проводять професор кафедри права та менеджменту у сфері цивільного захисту ЛДУ БЖД, доктор технічних наук, професор Олег Зачко і докторант, кандидат технічних наук Дмитро Кобилкін

України, кандидата педагогічних наук, доцента Ігоря Радомського «Педагогічне проектування як важлива складова професіоналізації педагогічного персоналу», в якій розглянуто поняття педагогічного проєкту, його основні параметри та фази життєвого циклу. Ці елементи проєктування можна застосувати під час реалізації пілотних проєктів неформальної освіти в галузі безпеки, що в своїй доповіді «Shaping human awareness in the field of safety. The role of the education for safety subject» представила Ізабелла ГрабовськаЛепчак, завідувач кафедри Головної школи пожежної служби у Варшаві. Зацікавлення також викликала доповідь доктора педагогічних наук, професора Олени Аніщенко, завідувача відділу андрагогіки Інституту педагогічної освіти і освіти дорослих імені Івана Зязюна НАПН України на тему «Університети третього віку: діяльність в умовах нестабільності», що присвячена проблематиці освіти дорослого населення в сучасних університетах, і може розглядатися як неформальна освіта в галузі геронтології. Низку доповідей

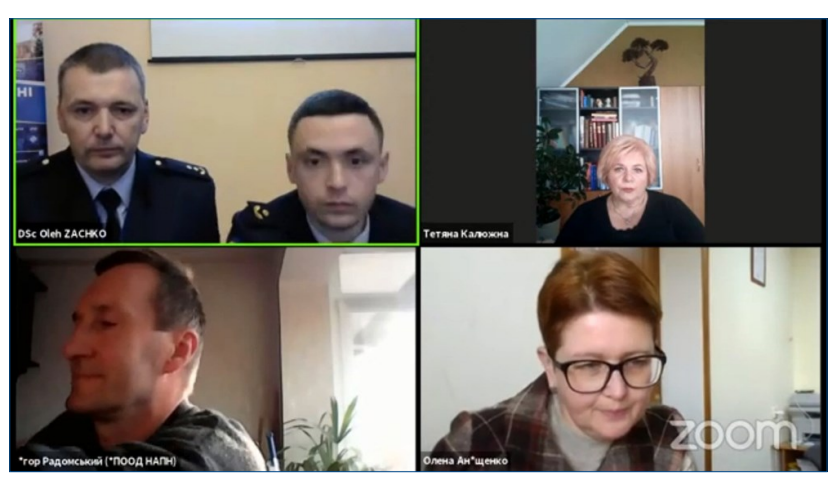

Фото 18. Учасники четвертої секції: доктор технічних наук, професор Олег Зачко та кандидат технічних наук Дмитро Кобилкін; кандидат філософських наук, старший науковий співробітник Тетяна Калюжна; кандидат педагогічних наук, доцент Ігор Радомський та доктор педагогічних наук, професор Олена Аніщенко 
було присвячено інформаційним технологіям в освіті (ад'юнкт кафедри інформаційних технологій і телекомунікаційних систем ЛДУ БЖД Юлія Кордунова), у наукових дослідженнях (кандидат технічних наук, доцент Тарас Гембара, доцент кафедри прикладної математики і механіки ЛДУ БЖД). Доктор сільськогосподарських наук, професор Андрій Кузик, проректор 3 науководослідної роботи ЛДУ БЖД зосередив увагу на інформаційній системі підтримки організації та супроводу конференцій, яку як пілотний проєкт було успішно реалізовано на цій конференції.

Семінари, воркшопи, майстер-класи та тренінги. На другий день роботи конференції проведено дев'ять семінарів, воркшопів, майстеркласів і тренінгів. Доповідачами на цих заходах були науково-педагогічні працівники ЛДУ БЖД, а також представники фірм, організацій та закладів освіти різних типів.

Тренінг «Надання екстреної психологічної допомоги» проводила викладач кафедри практичної психології та педагогіки ЛДУ БЖД Ксенія Березяк. Вона продемонструвала ефективні методи допомоги, що не є складними та можуть реалізовуватися рятувальниками в умовах виникнення надзвичайних ситуацій (фото 19).

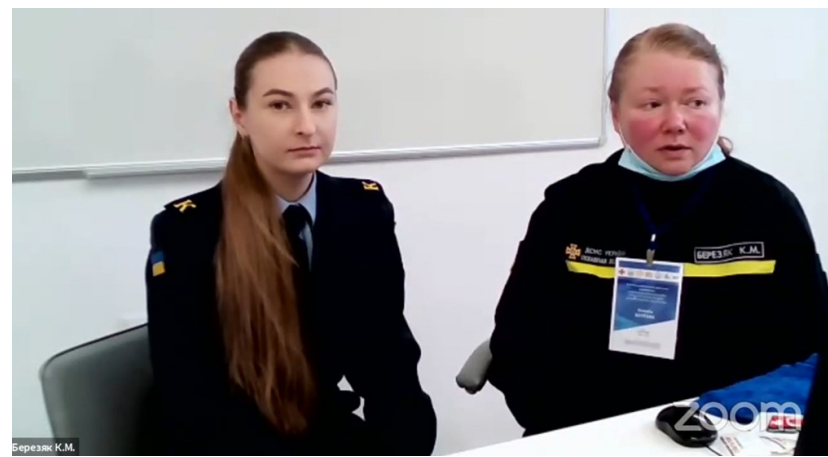

Фото 19. Викладач кафедри практичної психології та педагогіки ЛДУ БЖД Ксенія Березяк (праворуч) і курсантка Катерина Чміль проводять тренінг «Надання екстреної психологічної допомоги»

На воркшопі «Empowering virtual classes in the field of Smart Grid» Ольга Куселова - керівник міжнародного співробітництва в науці лабораторії архітектури знань Дрезденського технічного університету, Німеччина та кандидат технічних наук, доцент Дмитро Калюжний, доцент кафедри систем електропостачання та електроспоживання міст Харківського національного університету міського господарства імені О.М. Бекетова поділилися досвідом 3 розроблення інноваційного проєкту та проведення онлайн навчання в його рамках (фото 20). Учасниками цього англомовного

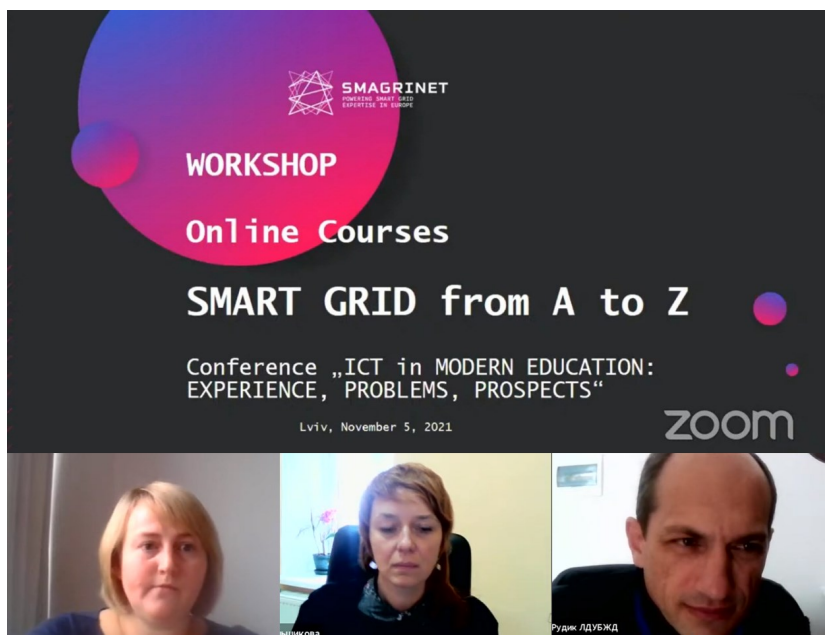

Фото 20. Організатор воркшопу «Empowering virtual classes in the field of Smart Grid» - керівник міжнародного співробітництва в науці лабораторії

архітектури знань Дрезденського технічного університету Ольга Куселова та його учасники -

кандидат фізико-математичних наук, доцент

Ольга Меньшикова та кандидат технічних наук, доцент Юрій Рудик

курсу є науково-педагогічні працівники та науковці ЛДУ БЖД, які після його завершення одержать не лише нові знання, а й набудуть навичок розроблення й організації подібних курсів, підвищать рівень володіння англійською мовою.

На семінарі «Синергія взаємодії університетів 3 IT-індустрією на прикладі бакалаврських програм, створених за підтримки Львівського ІT Кластеру» кандидат економічних наук, менеджер освітніх проєктів Львівського ІТ Кластеру Олег Леськів ознайомив учасників конференції з основними напрямами співпраці університетів Львова та компаній ITіндустрії, спрямованих на підготовку майбутніх фахівців для галузі інформаційних технологій (фото 21). Навчання за адаптованими освітньопрофесійними програмами дає змогу випускникам швидше працевлаштуватися і адаптуватися до сучасних умов праці, а роботодавці отримають програмістів, які відповідають потребам сучасних компаній. Кафедри ЛДУ БЖД, які готують фахівців у галузі інформаційних технологій, успішно співпрацюють з Львівським ITКластером, що дає змогу забезпечувати високий рівень навчання, брати участь у різноманітних заходах: хакатонах, конференціях, конкурсах тощо.

Сучасні технології використання інформаційних технологій та обладнання в процесі підготовки майбутніх перекладачів продемонструвала кандидат філологічних наук, доцент, доцент кафедри іноземних мов та перекладознавства лдУ БЖД Марія Іванченко в майстер-класі 


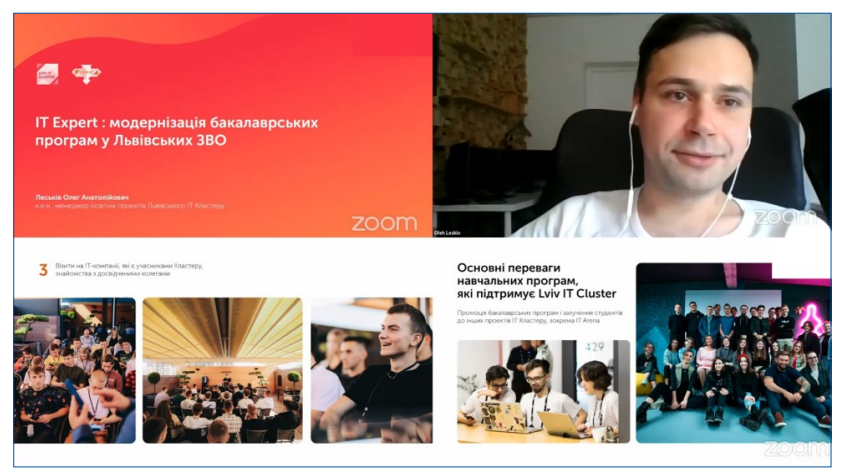

Фото 21. Менеджер освітніх проєктів Львівського IT Кластеру Олег Леськів проводить семінар «Синергія взаємодії університетів з IT-індустрією на прикладі бакалаврських програм, створених за підтримки Львівського IT Кластеру»

«Можливості IKT в опануванні синхронним перекладом» (фото 22). Вона не лише проаналізувала проблеми підготовки перекладачів-синхроністів, але і презентувала методики застосування апаратних та програмних засобів для синхронного перекладу. Відповідне сучасне обладнання широко застосовується в освітньому процесі ЛДУ БЖД. На базі лабораторії синхронного перекладу проводяться практичні заняття, що сприяють підвищенню ефективності навчання та викликають значний інтерес у студентів.

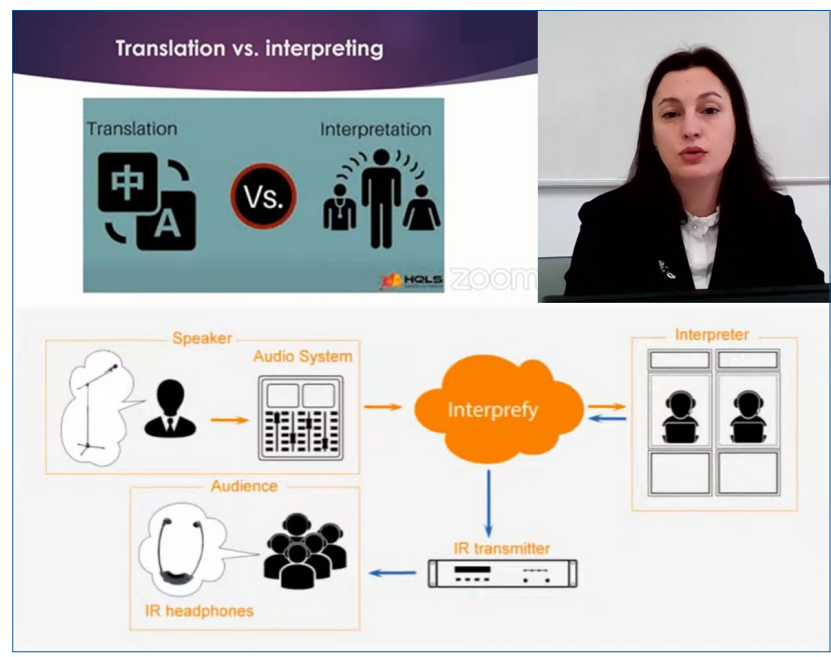

Фото 22. Кандидат філологічних наук, доцент, доцент кафедри іноземних мов та перекладознавства ЛДУ БЖД Марія Іванченко проводить майстер-клас «Можливості IKT в опануванні синхронним перекладом»

На воркшопі «Візуальне програмування та Low Code технології для швидкої реалізації програмних рішень» CEO компанії Ubraine Андрій Бідочко продемонстрував можливості та використання розробленого ними програмного забезпечення для візуального програмування під час розроблення додатків (фото 23). Їх використання умож-

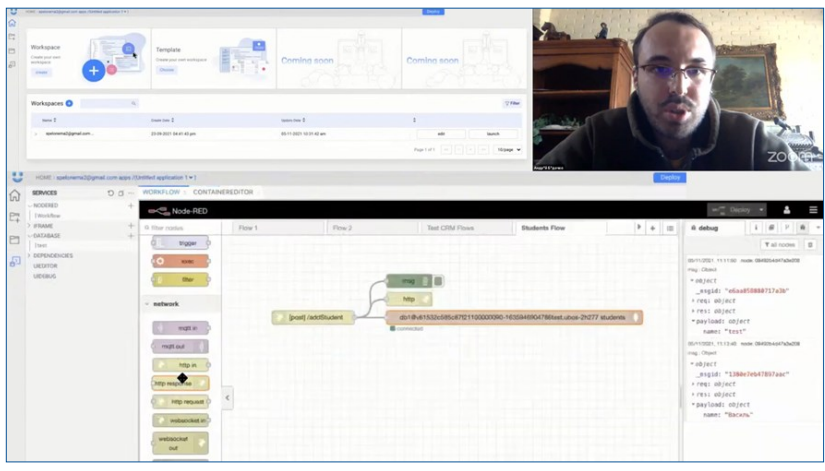

Фото 23. Воркшоп «Візуальне програмування та Low Code технології для швидкої реалізації програмних рішень» проводить СЕО компанії Ubraine Андрій Бідочко

ливлює зменшення обсягів написання програмного коду в результаті застосування методів візуального програмування. Організатор цього воркшопу на конкретних прикладах продемонстрував переваги запропонованих технологій програмування.

На семінарі «Досвід реалізації мобільного застосунку UniBell (розклад лДУ БЖД) в рамках виконання студентського R\&D проєкту» із розробками студентів ознайомили учасників науковий керівник, начальник кафедри інформаційних технологій та телекомунікаційних систем ЛДу БЖД, кандидат технічних наук, доцент Олександр Придатко та виконавець студент Віталій Дзень (фото 24). Це мобільний додаток, що розроблений на платформі Android та використовує дані з пакету програм «Деканат», розробленого компанією «Політек-Софт» для закладів вищої освіти. Упродовж тривалого періоду він використовується у ЛДУ БЖД. UniBell дає можливість студентам і викладачам швидко одержати інформацію про

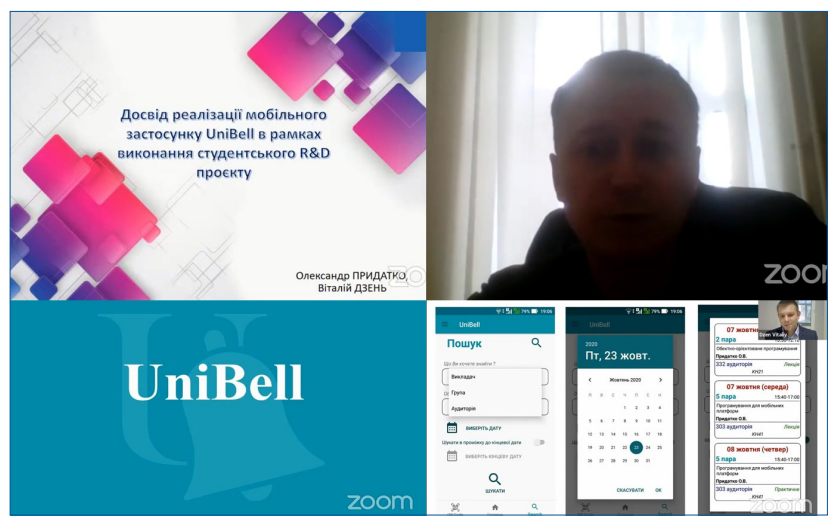

Фото 24. На семінарі «Досвід реалізації мобільного застосунку UniBell (розклад ЛДУ БЖД) в рамках виконання студентського R\&D проєкту» виступають науковий керівник, начальник кафедри інформаційних технологій та телекомунікаційних систем ЛДУ БЖД, кандидат технічних наук, доцент Олександр Придатко та виконавець студент Віталій Дзень 
розклад занять, місця їх проведення, хто проводить і т. ін. у зручному вигляді.

Можливості обладнання та методику проведення занять із застосуванням IKT навчальнонаукової лабораторії систем протипожежного захисту продемонстрував кандидат технічних наук Олег Пазен, доцент кафедри наглядовопрофілактичної діяльності та пожежної автоматики ЛДУ БЖД на семінарі «Використання інформаційних технологій в системах протипожежного захисту» (фото 25). Таку лабораторію створено в університеті недавно для підготовки фахівців у галузі пожежної та цивільної безпеки. Найсучасніше обладнання дозволяє моделювати виникнення надзвичайних ситуації та реагування на них. Однією з інновацій в навчально-науковій лабораторії $€$ спроектований науково-педагогічними працівниками університету та виготовлений на базі мікроконтролерів макет будинку підвищеної поверховості з системами протипожежного захисту та передбаченою можливістю демонстрації їх застосування в умовах пожежі або надзвичайної ситуації.

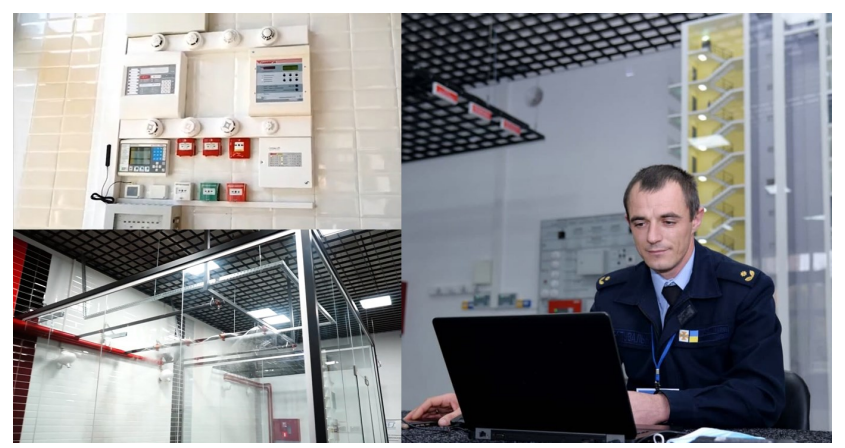

Фото 25. Семінар «Використання інформаційних технологій в системах протипожежного захисту» проводить кандидат технічних наук Олег Пазен, доцент кафедри наглядово-профілактичної діяльності та пожежної автоматики Лду БЖД

3 можливостями сучасного обладнання для навчальних лабораторій та програмного забезпечення, що розробляється для закладів освіти, ознайомив тренер ТОВ «Едпро Дистрибюшн», Diamond mozaLearn ICT Expert Дмитро Галько на семінарі «Використання сучасного обладнання та програмного забезпечення в освіті» (фото 26). Він продемонстрував можливості інтерактивних панелей та програмного забезпечення Mozaik Education, що сприяють демонстрації предметів, явищ та процесів, котрі вивчаються, у зручній та доступній формі. Було також продемонстровано обладнання для STEM-навчання, що дає змогу на основі вмінь програмування створювати різнома-

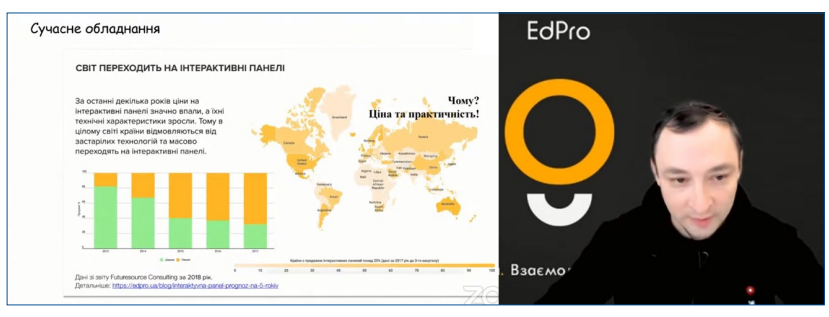

Фото 26. На семінарі «Використання сучасного обладнання та програмного забезпечення в освіті» виступає тренер ТОВ «Едпро Дистрибюшн»,

Diamond mozaLearn ICT Expert Дмитро Галько

нітні моделі методом 3D-друку, фрезерування, а також за допомогою потужного лазера.

Використання спеціалізованих мобільних додатків, що дають можливість «розібрати» автомобіль будь-якої марки та врахувати це під час проведення рятувальних робіт продемонстрували на майстер-класі «Застосування IКТ під час відпрацювання вправ по деблокуванню потерпілих» старший викладач кафедри експлуатації транспортних засобів та пожежно-рятувальної техніки ЛДУБЖД кандидат технічних наук, доцент Андрій Гаврилюк, ад'юнкт Микола Швець та заступник начальника кафедри цивільного захисту та комп'ютерного моделювання екогеофізичних процесів ЛДУ БЖД, кандидат наук з державного управління Віктор Ковальчук (фото 27). Майстер-клас проводився у тренінговому центрі рятувальних робіт з елементами моделювання надзвичайної ситуації на транспорті та діями 3

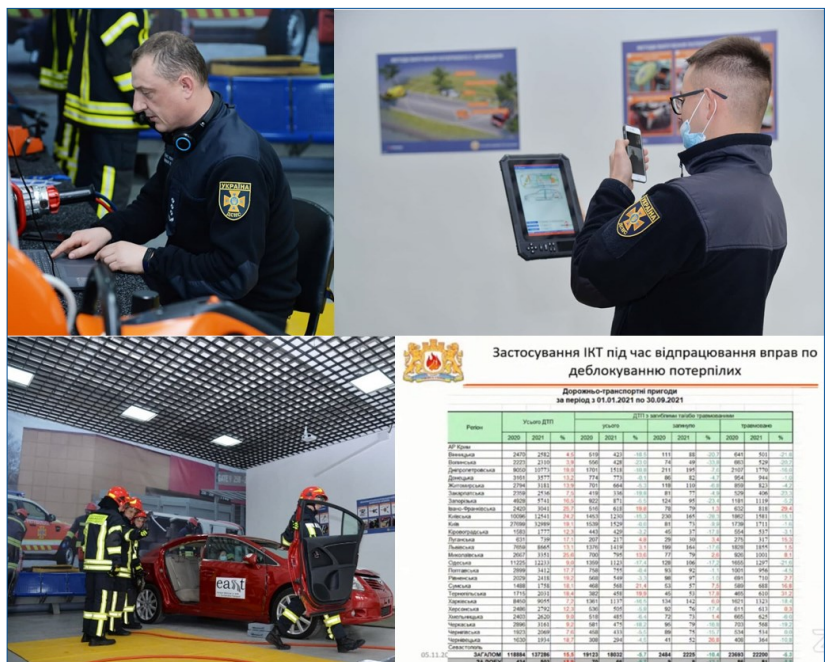

Фото 27. Майстер-клас «Застосування IКТ під час відпрацювання вправ по деблокуванню потерпілих» проводять заступник начальника кафедри цивільного захисту та комп'ютерного моделювання екогеофізичних процесів ЛДУ БЖД, кандидат наук з державного управління Віктор Ковальчук, старший викладач кафедри експлуатації транспортних засобів та пожежно-рятувальної техніки ЛДУ БЖД кандидат технічних наук, доцент Андрій Гаврилюк, ад'юнкт Микола Швець та курсанти ЛДУ БЖД 
деблокування потерпілих з використанням автомобіля-трансформера Toyota Avensis.

Усі семінари, воркшопи, майстер-класи та тренінги викликали значний інтерес учасників конференції, які ставили запитання та висловлювали свою думку щодо продемонстрованих можливостей практичного застосування IKT у закладах вищої освіти.

Підсумки роботи конферениії. На підсумковому пленарному засіданні виступили керівники секцій, які прозвітували про роботу на секційних засіданнях та виокремили доповіді, що виявили значний інтерес учасників. Керівники секцій надали пропозиції до проєкту висновків і рекомендацій конференції. Від співорганізаторів виступила доктор педагогічних наук, професор, членкореспондент НАПН України Лариса Лук'янова директор Інституту педагогічної освіти і освіти дорослих імені Івана Зязюна НАПН України, яка подякувала організаторам конференції та наголосила на важливості застосування інформаційнокомунікаційних технологій для сучасної освіти.

Організачійно-технічні аспекти. Заслуговують на увагу деякі організаційно-технічні питання, застосовані організаційним комітетом в процесі підготовки і проведення цієї конференції, що базуються на IKT. 3 метою ефективної організації підготовки та проведення конференції, забезпечення комунікації між організаційним комітетом і учасниками, планування та виконання різноманітних завдань організаційний комітет вирішив застосовувати онлайн-систему менеджменту конференцій, яка $є$ різновидом систем керування вмістом вебсайтів (CMS-систем). У ЛДУ БЖД з 2017 року використовувалася CMS-система Open Conference System, розробником якої $€$ Public Knowledge Project - ініціатива університетів Канади з розроблення безкоштовного програмного забезпечення для удосконалення якості і охоплення наукових публікацій. Ії̈ застосовують зарубіжні та вітчизняні університети, зокрема Київський політехнічний інститут ім. Ігоря Сікорського та Львівський національний університет ім. Івана Франка. Як відомо, ця система давно не оновлювалася, $є$ не дуже зручною в користуванні для організаторів та учасників і має певні обмеження, наприклад, не передбачає відкритого (гостьового) доступу до інформації, розрахованої на всіх бажаючих, не дозволяє розмістити на платформі збірник матеріалів конференції тощо. За даними сайту Public Knowledge Project, розробники планували вихід нової версії, що затримався ймовірно з причин складності та наявності інших пріоритетів. Тому було вирішено перейти на іншу систему менеджменту конференцією, що є більш зручною та функціональною у порівнянні з Open Conference System. Таку систему було вибрано 3 урахуванням результатів аналізу наявних програмних засобів, а також із залученням працівників відділу інформаційних технологій та захисту інформації ЛДу БЖД її введено в експлуатацію. Це система менеджменту конференцій Indico, що $\epsilon$ безкоштовною, успішно застосовується за кордоном та в Україні. Розробником Indico $\in$ CERN Європейська організація з ядерних досліджень (Женева). В цій системі було створено вебсайт конференції (див. рис. 1) та наповнено необхідною інформацією (рис. 3).

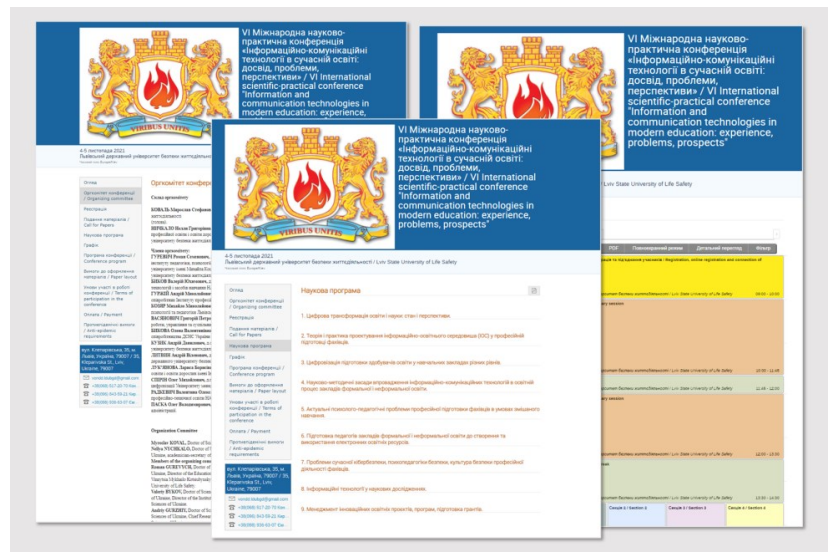

Рис. 3. Сторінки вебсайту конференції в системі менеджменту конференцій Indico

Учасники конференції мали можливість зареєструватися та подати матеріали (статті, презентації тощо), ознайомитися з науковою програмою, графіком роботи, вимогами до оформлення матеріалів, умовами участі, зокрема протиепідемічними вимогами для бажаючих взяти участь очно. Система забезпечувала інформування зареєстрованих учасників VI конференції засобами електронної пошти і нагадування про важливі події. Засобами системи було розроблено дизайн бейджів і квитків для учасників конференції. Для реєстрації прибуття учасників члени оргкомітету завантажили мобільний додаток Indico Check-In (наявні версії для Android та IOs), з допомогою якого за списком зареєстрованих учасників або за QR-кодом на квитку планувалася реєстрація в день проведення конференції (рис. 4).

Організаційний комітет очікував, що конференція відбудеться у звичайному режимі з приїздом учасників до Львова. Лише окремі доповіді планувалося заслухати із застосуванням телекомуні- 


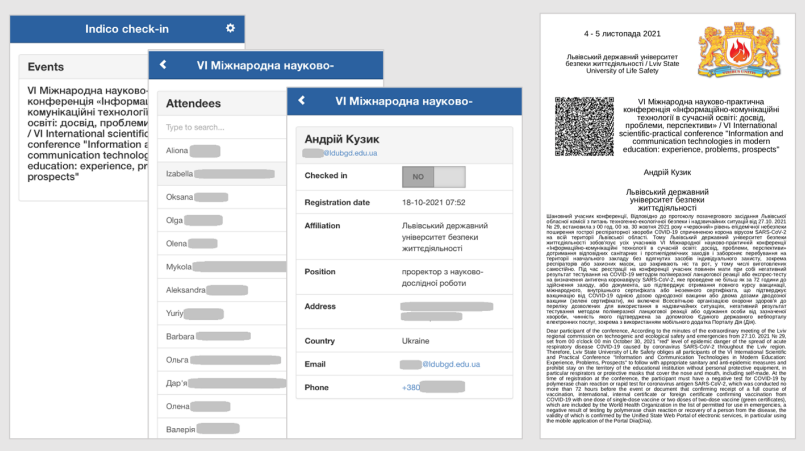

Рис. 4. Мобільний додаток Indico Check-In та квиток учасника конференції з QR-кодом, що генерується системою Indico і сканується мобільним додатком (головна сторінка конференції, сторінка із списком учасників, дані про учасника, квиток учасника)

каційних засобів. Однак складна епідемічна ситуація в Україні, спричинена пандемією COVID19, змусила організаторів та учасників застосувати онлайн-форму проведення цієї конференції. 3 урахуванням особливостей онлайн-форми проаналізовано наявне та обрано найбільш ефективне і зручне програмне забезпечення для проведення відеоконференції - платформу Zoom. Відповідно до цього запропоновано проводити пленарні та чотири секційні засідання, відібрано та згруповано доповідачів для обох видів засідань. Сформовану програму з гіперпосиланнями для підключення учасників оргкомітет розмістив на Web-сторінці конференції. Оскільки платформа Zoom у межах придбаних ліцензій обмежує кількість учасників до 100, тому було додатково організовано онлайн-трансляцію конференції на каналі YouTube університету. За посиланням усі бажаючі мали можливість бути присутніми на конференції або переглянути пленарні чи секційні засідання у записі. В рамках конференції організаційний комітет запланував низку різних заходів - виставок видавців, виробників обладнання та програмного забезпечення у галузі IKT презентацій розробок працівників тощо. Однак у зв'язку з переважною участю онлайн довелося внести коригування та запланувати проведення семінарів, воркшопів, майстер-класів та тренінгів 3 урахуванням використання платформи Zoom. Оскільки безпосередньо в день проведення конференції неможливо було провести реєстрацію з використанням засобів Indico, учасникам було запропоновано зареєструватись 3 допомогою Google-форм.

Висновки та рекомендації конференції. За результатами доповідей на пленарному та секційних засіданнях, їх обговорення, а також врахо- вуючи результати проведення семінарів, воркшопів, майстер-класів та тренінгів організаційним комітетом було сформульовано низку висновків та рекомендацій, що мають значення для освітньої сфери та застосування IКT. Висновки і рекомендації можуть бути дорожньою картою у сфері застосування IKT у сучасній освіті. Наведемо основні з них.

В Україні розвиток та впровадження IKT в усі галузі відбувається відповідно до законів України «Про Концепцію Національної програми інформатизації» від 4 лютого 1998 р. № 75/98-ВР, «Про Національну програму інформатизації» від 4 лютого 1998 р. № 74/98-ВР, «Про захист інформації в інформаційно-телекомунікаційних системах» від 5 липня 1994 року № 80/94-ВР, постанов Кабінету Міністрів України «Питання Міністерства цифрової трансформації» від 18 вересня 2019 р. № 856 та «Деякі питання цифрового розвитку» від 30 січня 2019 р. № 56, розпоряджень Кабінету Міністрів України «Про схвалення Стратегії розвитку інформаційного суспільства в Україні» від 15 травня 2013 р. № 386-р та «Деякі питання цифрової трансформації» від 17 лютого 2021 р. № 365-p.

Від початку XXI ст. IКТ швидкими темпами впроваджуються в освітню діяльність, підвищуючи якість навчання. Цьому процесу сприяє законодавство у сфері освіти і науки. Міністерство освіти і науки України завершило громадське обговорення та планує ухвалення Концепції цифрової трансформації освіти і науки на період до 2026 року.

Інформатизація освіти набирає системного характеру, змінюючи систему освіти в цілому, та сприяючи перебудові змісту й організації навчально-виховної діяльності. Новітні та традиційні методи навчання гармонійно доповнюють один одного як частини єдиного освітнього середовища. Використання когнітивних можливостей IKT має сприяти розв'язанню педагогічних завдань, що складно або неможливо розв'язати традиційними методами.

3 урахуванням наукових розробок Інституту інформаційних технологій і засобів навчання НАПН України та інших академічних установ, основними стратегічними напрямами інформатизації вищої освіти $є$ : розвиток вітчизняної науковоосвітньої інфраструктури; налагодження та взаємодія усіх рівнів управлінських інформаційних систем; розширення індустрії електронних освітніх ресурсів і SMART-технологій, зростання мобі- 
льності навчання; використання інтегрованих IKTрішень тощо.

Широка інформатизація зумовлює ґрунтовне оновлення поглядів на завдання та напрями використання IKT в усіх аспектах діяльності закладів вищої освіти. Запорукою успішного впровадження новітніх технологій та інноваційних дидактичних засобів на їх основі є розроблення дидактичної, технічної та методичної підтримки процесу використання ІКТ і відповідного науковометодичного забезпечення. Найбільш перспективною моделлю інформатизації закладу вищої освіти $€$ створення в ньому інформаційноосвітнього середовища, яке дасть можливість підвищити інтенсивність і якість навчання та виховання майбутніх фахівців завдяки долученню до невичерпних ресурсів єдиного інформаційного простору й оптимізації організаційнопедагогічних умов використання IKT.

Перспективним є проєктування та впровадження в освітню діяльність різноманітних апаратнопрограмних комплексів, спрямованих на моделювання професійної діяльності майбутніх фахівців у різноманітних умовах, у тому числі, екстремальних, пов'язаних із ризиком для життя та здоров'я, а також моделювання безпечного майбутнього. Побудова та використання таких навчальних комплексів потребує одночасного розроблення відповідних методик і технологій навчання та їх психологічного супроводу.

Успішне впровадження електронних освітніх ресурсів потребує застосування проєктно орієнтовного підходу одночасно з виявленням відповідних теоретичних і методологічних засад використання аудіовізуальних засобів, мультимедійних презентацій, електронних видань, а також вправ, розміщених у віртуальному навчальному середовищі. Інформатизація освітнього процесу, проєктування та реалізація інформаційно-освітнього середовища закладу створює оптимальні умови для реалізації індивідуальних освітніх траєкторій здобувачів освіти, зокрема у вигляді електронних навчальних SMART-комплексів.

Сучасні когнітивні трансдисциплінарні IKTтехнології спроможні конструктивно вирішити питання тематичної синхронізації навчальнопізнавальних завдань за різними дисциплінами.

Активно розвиваються можливості графічних інформаційних технологій в освіті, передусім у прикладних напрямах із залученням спеціалізованих математичних процесорів відповідно до потреб освітнього і наукового процесу наскрізної професійної підготовки фахівців технічного профілю. Особливе значення мають методи комп'ютерного моделювання в навчальному процесі та наукових дослідженнях, зокрема віртуальне моделювання явищ і процесів, у тому числі ризиконебезпечних, екстремальних ситуацій.

В умовах пандемії COVID-19 зростає потреба вдосконалення дистанційної освіти та реалізації змішаного навчання, що потребує проєктування та впровадження віртуальних навчальних середовищ і систем управління навчанням, застосування яких дає змогу об'єднати учасників освітнього процесу, забезпечити їх найсучаснішим навчальним матеріалом, мультимедійними засобами і довідковою інформацією, залучити до викладання провідних науковців і практичних працівників, проводити відеоконференції, відеотрансляції, телемости та інші наукові й освітні заходи. Водночас, широке застосування IKT потребує належного інформаційного захисту та дотримання заходів із кібербезпеки учасниками освітнього процесу.

Важливим напрямом ефективного застосування IKT $є$ участь закладів у соціальних мережах, що дає змогу використати переваги цих неформальних об'єднань із метою інформування та популяризації освіти і науки та інтегрувати їх в освітній процес. Актуальними є завдання розроблення мобільних версій віртуальних освітніх середовищ, різноманітних спеціалізованих навчальних і довідкових програмних продуктів, а також педагогічних технологій їх застосування.

Використання досвіду електронного навчання в системах вищої освіти європейських країн сприятиме виробленню єдиних стандартів та уніфікованого управління компонентами інформаційноосвітнього середовища, ефективній інформатизації та модернізації української освіти.

Важливим на сучасному етапі модернізації вищої освіти в Україні $€$ підвищення статусу закладів вищої освіти із специфічними умовами навчання з урахуванням важливості завдань, що ставить перед ними держава та суспільство, зокрема закладів освіти ДСНС України, котрі здійснюють підготовку фахівців цивільного захисту. Вони втілюватимуть цінності громадянського суспільства, якісно й оперативно, із застосуванням новітньої техніки і технологій вирішуватимуть проблеми, що з'являються в процесі виконання потенційно небезпечних аварійнорятувальних, пошукових та інших робіт і завдань. Цю підготовку доцільно здійснювати інтегровано, 
на засадах психопедагогіки безпеки як субдисципліни педагогічної науки. У цьому контексті теоретичне осмислення соціально-психологічних і психолого-педагогічних основ професійної підготовки курсантів і студентів $€$ важливим чинником модернізації такого закладу вищої освіти.

Актуальною залишається потреба створення та використання комп'ютеризованих тренажерівсимуляторів спеціалізованого аварійно-рятувального обладнання 3 ліквідації різноманітних надзвичайних ситуацій, а також відповідної методики для відпрацювання вправ із їх застосування. Особливої уваги потребує розвиток інтерактивних технологій навчання та виховання, а саме розроблення й застосування електронних освітніх ресурсів на основі сучасних дидактичних підходів для організації та реалізації на практиці різноманітних видів і форм інноваційного навчання.

За результатами роботи конференції розроблено низку рекомендацій закладам освіти різних рівнів у контексті впровадження інформаційнокомунікаційних технологій:

- проводити створення і розгортання відкритих освітньо-наукових інформаційних систем; електронних наукових і освітніх ресурсів для інформаційного забезпечення психолого-педагогічної науки й освітньої практики; хмарних систем інформатизації освіти; інструментів організації та інформаційно-технологічної підтримки освітнього процесу; впровадження смарт-пристроїв із метою неперервного управління навчанням;

- впроваджувати новітні цифрові технології, технології дистанційного навчання та інтернеторієнтовані педагогічні технології, вивчати і поширювати кращий вітчизняний і зарубіжний досвід застосування новітніх IKT та інноваційних методик професійної освіти, налагоджувати міжнародну співпрацю з цих напрямів;

- зосередити увагу на створенні та впровадженні освітніх технологій для мобільних комунікаційних пристроїв, засобів віртуальної та доповненої реальності, автоматизованих систем з розподіленими інформаційними ресурсами і хмарних сервісів;

- продовжити розробку інноваційних освітніх проектів у контексті розвитку закладів освіти ДСНС України, передусім сучасних засобів організації та інформаційно-технологічної підтримки навчальнопізнавальної та науково-дослідницької діяльності курсантів і студентів;

- посилити дослідження психологічних та етичних аспектів застосування IKT в освіті, в тому числі із залученням соціальних мереж;
- ініціювати дослідження проблем захисту інформації в освітніх мережах закладу й освітніх порталах;

- для вироблення стратегії застосування найбільш продуктивних інновацій, що базуються на IKT, необхідні підготовка і схвалення Програми інформатизації закладу освіти, що описує комплекс заходів усіх служб і підрозділів закладу, спрямованих на створення інформаційноосвітнього середовища;

- досліджувати дидактичні можливості цифрових інструментів і програм, а також забезпечити науково-методичний супровід професійної підготовки здобувачів освіти з їх використанням у педагогічній практиці як у дистанційному, так і в офлайн режимі;

- заохочувати педагогічних працівників до розвитку власної ІКТ-компетентності, ефективного та цілеспрямованого використання цифрових засобів й інструментів у освітньому процесі, проведення ініціативних наукових досліджень 3 упровадження комп'ютерно орієнтованого навчання;

- організовувати, проводити і брати широку участь у науково-практичних заходах із впровадження ІКТ та інноваційних методик навчання у професійній освіті.

Висновки. Висновки і рекомендації конференції як логічні результати роботи пленарних та секційних засідань свідчать про значну кількість та багатоаспектність педагогічних проблем, пов'язаних із застосуванням інформаційно-комунікаційних технологій в діяльності сучасного освітнього закладу, та успішність їх вирішення науковцями України та інших країн.

Передовий досвід застосування IKT, продемонстрований учасниками в рамках конференції, рекомендуємо впроваджувати у процес викладання різноманітних дисциплін, розвиваючи при цьому матеріально-технічну базу та власні інформаційні технології, застосовуючи переваги засобів телекомунікацій, що особливо актуальне в умовах дистанційного та змішаного навчання, спричинених пандемією COVID-19.

Проведення науково-практичної конференції за напрямом IKT в освіті зумовлює доцільність широкого застосування інноваційних організаційно-технічних рішень, які підвищують ефективність роботи організаційного комітету в процесі підготовки та проведення заходу, спрощують процеси інформування учасників, їх реєстрації, подання матеріалів та комунікацію з організаторами. 


\section{СПИСОК ВИКОРИСТАНИХ ДЖЕРЕЛ}

Козяр, М.М., \& Харчук, А.І. (ред.). (2017). Львівський державний університет безпеки життєдіяльносmi (1947-2017 рр.) : ювілейна книга. Львів.

лДУ БЖД. (2021, 4 листопада). Пленарне засідання 04.11.2021. https://youtu.be/mUgo9PVw5dl

лДУ БЖД. (n.d.) Головна [YouTube канал]. YouTube. https://www.youtube.com/user/harciy1993
Львівський державний університет безпеки життєдіяльності. (2021). VI Міжнародна науково-практична конференція "Інформаційно-комунікаційні технології в сучасній освіті: досвід, проблеми, перспективи». https://indico.ldubgd.edu.ua/event/1/

Харчук, А.І. (ред.). (2007). Від курсів до університету (1947-2007) : Пропам'ятна ювілейна книга Львівського державного університету безпеки життєдіяльності. Львів.

\section{PEDAGOGY AND PSYCHOLOGY OF LIFE SAFETY \\ Based on the results of the 6th International Scientific and Practical Conference "Information and Communication Technologies in Modern Education: Experience, Problems, Prospects"}

Myroslav Koval

DSc in Pedagogy, Professor, Rector, Lviv State University of Life Safety, Lviv, Ukraine Nellia Nychkalo

DSc in Pedagogy, Professor, Full Member (Academician) of NAES of Ukraine, Academician Secretary of the Division of Professional and Adult Education, National Academy of Educational Sciences of Ukraine, Kyiv, Ukraine Andrii Kuzyk

DSc in Agriculture, Professor, Vice-Rector for Research, Lviv State University of Life Safety, Lviv, Ukraine

Abstract. The paper characterises various aspects of preparation and conduct, summarises the results of the 6th International Scientific and Practical Conference "Information and Communication Technologies in Modern Education: Experience, Problems, Prospects". The conference took place on November 4-5, 2021, at Lviv State University of Life Safety, following the work plan of the State Emergency Service of Ukraine and the National Academy of Educational Sciences of Ukraine. It was launched in 2006 by the Ministry of Emergency Situations of Ukraine and the National Academy of Educational Sciences of Ukraine.

In 2021 the conference organisers were: National Academy of Educational Sciences of Ukraine, Division of Professional and Adult Education of NAES of Ukraine, Ivan Ziaziun Institute of Pedagogical and Adult Education of NAES of Ukraine, Institute of Vocational Education and Training of NAES of Ukraine, Institute of Information Technologies and Learning Tools of NAES of Ukraine, Lviv State University of Life Safety as a structural subdivision of the State Emergency Service of Ukraine and Department of Education and Science of the Lviv Regional State Administration.

At the plenary sessions, Ukrainian and foreign researchers - well-known specialists in the field of professional pedagogy, and pedagogy and psychology of life safety - made scientific reports. Their reports set out the theoretical foundations, experience in the use of information and communication technologies in the educational process of modern education institutions and substantiate the prospects for digitalisation of specialists' of new generation training.

Interesting discussions took place at the meetings of four sections: 1. Digital transformation of education and science: status and prospects. Digitisation of training of students in education institutions of different levels. Problems of modern cybersecurity, security psychopedagogy, security culture of professional activity of specialists. 2. Theory and practice of designing information and educational environment in the training of specialists. Scientific and methodological principles of introducing information and communication technologies in the educational process of formal and non-formal education institutions. 3. Actual psychological and pedagogical problems of professional training in blended learning. 4. Training of teachers of formal and non-formal education institutions to create and use electronic educational resources. Information technologies in research. Management of innovative educational projects, programmes, preparation of grants. The work of the sections was managed by well-known representatives of higher education institutions' academic staff.

During the conference, there was an exchange of innovative experiences in using information and communication technologies in education institutions. The conference participants took part in seminars, workshops, masterclasses, and training conducted by the academic staff of Lviv State University of Life Safety, other education and research institutions, and companies engaged in production and educational activities in the field of information technology.

At the final meeting, the results of the work of the sections were discussed. The conclusions and proposals to the recommendations of the conference were substantiated. The most important of them are outlined in this paper. In total, more than 100 people from seven countries - Bulgaria, Great Britain, Canada, Moldova, Germany, Poland, and Ukraine took part in plenary, sectional meetings, and other events, 60 of them made scientific reports and reports.

The paper also highlights the organisational and technical aspects of the conference, including the use of the online platform Zoom and the conference management system Indico.

Based on the results of the discussion of topical issues of the use of information and communication technologies in modern education, innovative approaches and methods of organising the educational process in higher education institutions in the context of digitalisation are proposed. It is recommended to introduce the ideas of innovative experience in the use of ICT into the educational process of education institutions of various types and forms of ownership, especially distance and blended learning in the context of the COVID-19 pandemic.

Keywords: pedagogy; psychology; life safety; professional training; information and communication technologies; digitalisation.

Дата публікації: 30 грудня 2021 р. 
Кадри з документального фільму, присвяченого практичній підготовці курсантів у Львівському державному університеті безпеки життдіяльності

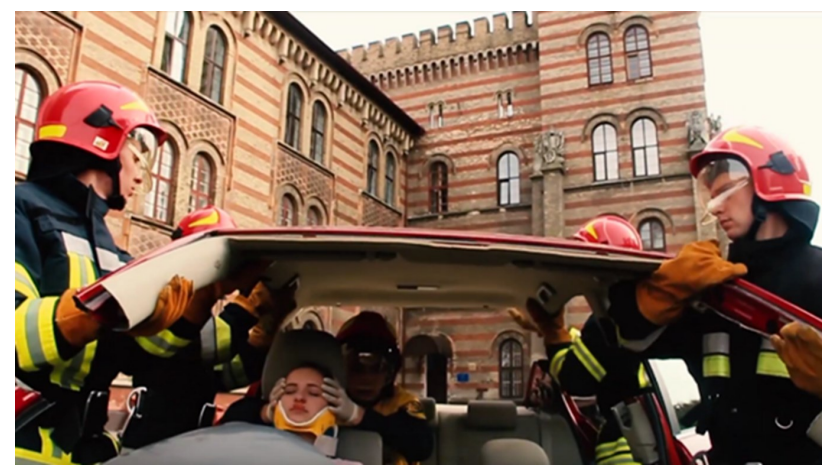

Курсанти виконують вправи з деблокування потерпілого внаслідок ДТП із застосуванням автомобіля-трансформера

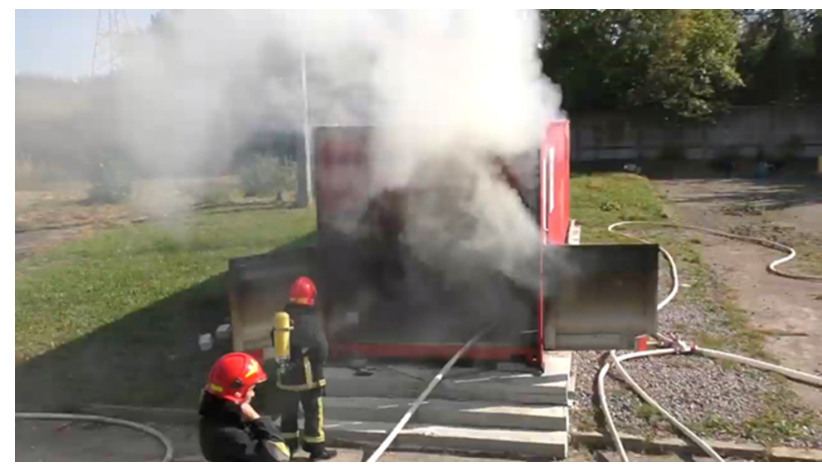

Практичні заняття на вогневому тренажері контейнерного типу

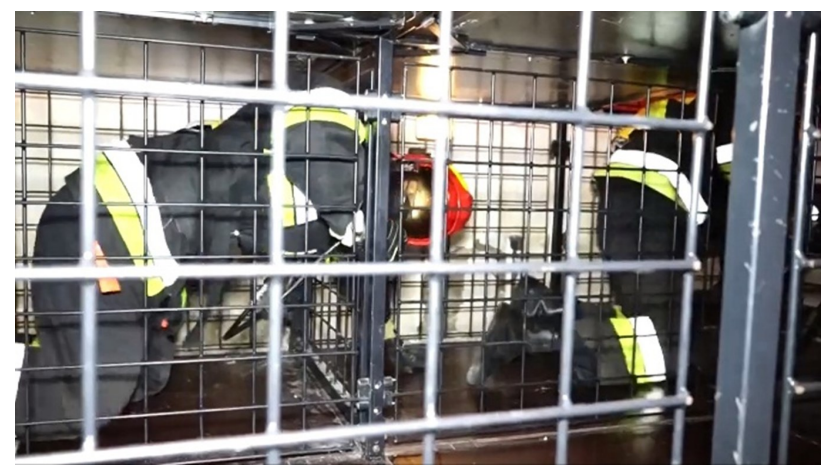

Проходження курсантами тренувальної стежки у психолого-тренувальному полігоні

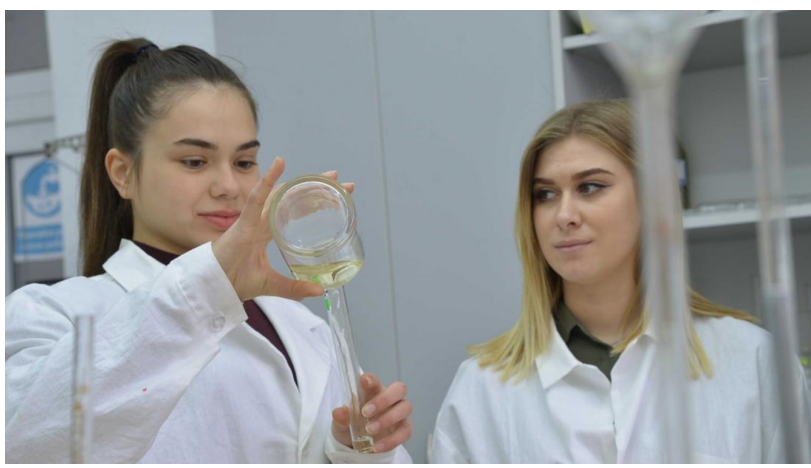

Дослідження якості питної води в лабораторії екологічної безпеки

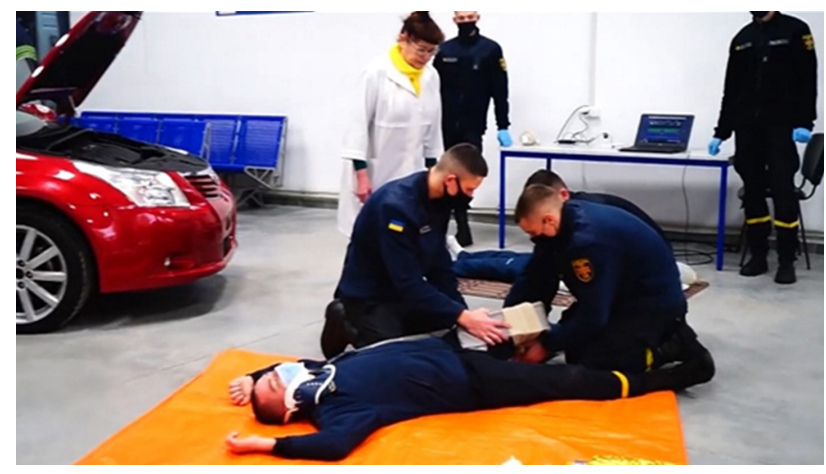

Надання домедичної допомоги потерпілому внаслідок ДТП

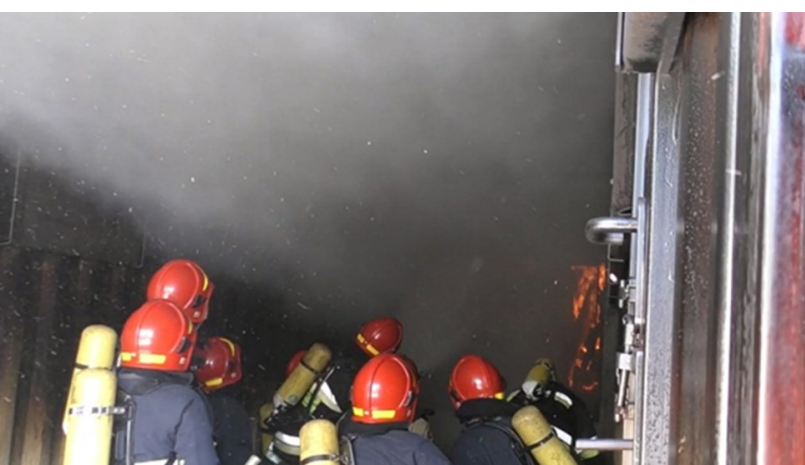

Курсанти виконують завдання в умовах, максимально наближених до умов реальної пожежі

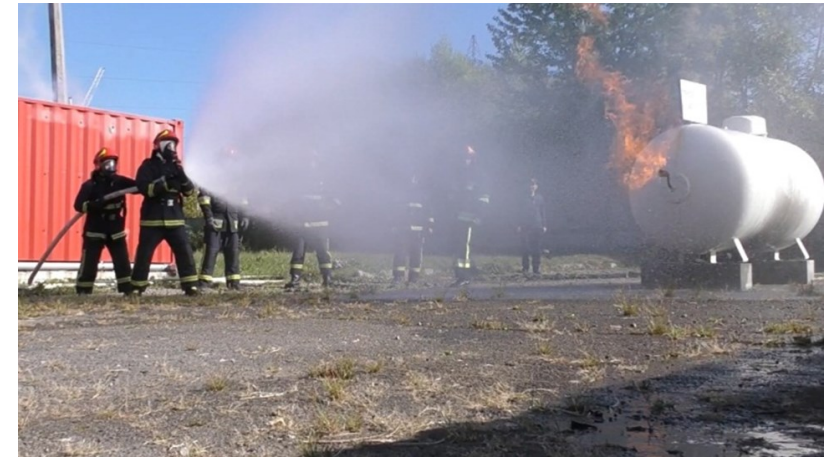

Практичне заняття з тактики гасіння газового резервуару

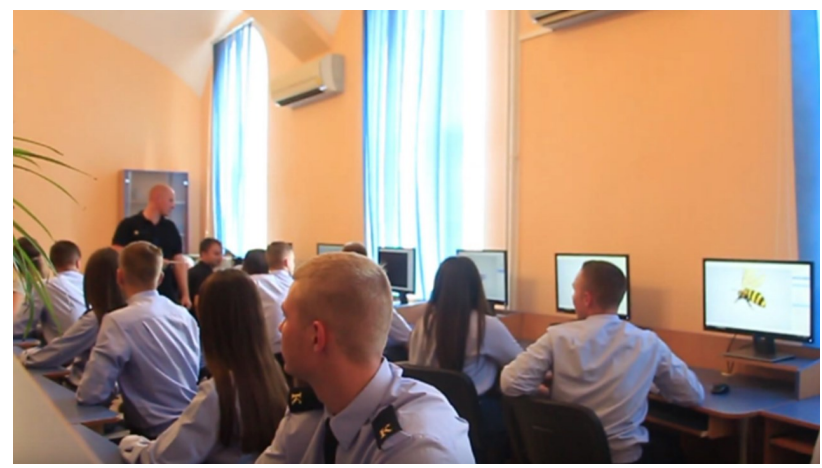

Заняття з комп'ютерного моделювання 